\title{
ON TUBE-FRAME GOODS WAGONS \\ OF LIGHT WEIGHT AND LARGE CAPACITY, AND THEIR EFFECT UPON THE WORKING EXPENSES OF RAILWAYS.
}

By Mr. M. R. JEFFERDS, of LoNDon. Communicated throvge Mr. Henry J. Martign.

The best construction of Railway Goods Wagons is a subject which up to the present time seems hardly to have received all the attention it deserves at the hands of English engineers and railway managers. Its consideration is of great importance to the problem of cheap and remunerative transport between producer and consumer, in order that the manifold industries of Great Britain may keep pace with those of other countries, which are now gradually and surely making large inroads into the business of the manufacturing and agricultural communities of the United Kingdom.

Comparing the present build of goods wagons on English railways with the wagon constructed by George Stephenson to carry the water tank for his "Rocket" locomotive in 1829, it will be observed that there has been no change in principle and but little in construction during the sixty years that have since elapsed. Goods wagons such as are still running in this country are no longer to be found in America. Those used in the United States are constructed similarly in principle to street vans, but have a king bolt or swivel pin at both ends, instead of at the front end only, so as to permit of their being turned round in their own length, and of their running round curves of a radius no greater than the length of the wagon; and they have a four-wheel truck or bogie under each swivel bolt, so as to distribute the load, and to take up any jolt caused by unevenness of road, without imparting the whole vibration or shock to the body of the vehicle and its load. 
There are many ways of building these wagons. Timber solebars have generally been considered the best, prior to the introduction of the tube-frame now to be described. Frames made of channel iron or steel have been tried, but have been found too rigid; any shock received by them from the road is immediately transmitted back again to the rails, and the vibration tells on the many rivets holding the frame together. With timber sole-bars the limit of elasticity is reached at loads of about 20 tons, unless the wagon is made too heary, in which case it has too much dead weight in proportion to the load it is to carry. In order to meet the requirements of modern railway goods traffic, which is being dealt with in America at only one-third of what it costs in this country, and in order to keep pace with the rapid increase in these requirements, by providing increased carrying capacity with diminished dead weight and with economy in repairs and less frequent renewals, some other material than wood is desirable for the construction of the wagons. Lightness and simplicity, combined with great strength and durability, are what is demanded; and as iron and steel have already been adopted for bridges and ships, so must they now be applied to the construction of railway wagons. A tube of any size has greater stiffiness longitudinally and at the same time also greater elasticity transversely than the same weight of metal in any other form; so that at the present time the strongest and lightest goods wagons built in America, possessing also the greatest elasticity and the largest carrying capacity, are the TubeFrame Wagons forming the subject of the present paper, designed by Messrs. Goodfellow and Cushman.

The construction of these wagons is shown in Plates 137 to 141, and general views of wagons with four different kinds of bodies are added in Plates 142 to 145. In Plate 137, Fig. 1 is a plan and Fig. 2 a side elevation of one of the low-sided or gondola wagons with drop ends, Plate 142.

Body of Wagon.-The body of the wagon, Plates 138 and 139, rests upon two transom bolsters $B$, one at each end, which are carried upon the bogie trucks by a ball-and-socket joint centred on a king bolt or swivel pin, with side bearings K, Fig. 8, permitting 
$\frac{3}{4}$ inch vertical play or tilting, that is $\frac{3}{8}$ inch on each side. Each bolster is composed of two bars of oak, 4 ins. deep by $7 \frac{1}{4}$ ins. broad and $7 \mathrm{ft} .8$ ins. long, and is faced with channel iron along its front and back edges. The two bars are fixed together by placing one of the channel irons, flanges upwards, across two blocks or horses, and laying therein the chamfered edge of one of the bars, upon which the truss rod $R$ is then laid in the grooves made for it, Fig. 8. Upon this is now placed the other bar of the bolster, and the other channel iron is then fixed on its chamfered edge. The whole is fastened together by four 1-inch bolts of $1 \mathrm{ft.} 9$ ins. length, their heads and ends projecting far enough to secure the pieces $F$ for the longitudinal tubes to rest in, Figs. 4 and 18. To each bolster there are sixteen of these pieces, two of which are placed upon each end of each bolt, in such a manner that when the bolt is screwed up tight its head bears equally on the two pieces $F$ in front of the bolster, and the nut bears equally on the two behind. The centre socket or concave plate of the ball-and-socket swivel-joint is fastened to the underside of the bolster; and flat plates $M$, forming circular ares struck from the centre joint, are also fixed on the underside of the bolster, to serve as side bearings in swivelling and to prevent tilting over sideways. As these flat plates $\mathrm{MI}$ and the bearings $\mathrm{K}$ beneath them are entirely hidden by the bolster $B$ in the plan, Fig. 3 , they are drawn separately alongside the bolster; and their actual position under the bolster is indicated by dotted lines. A king bolt or swivel pin, 1 ft. 5 ins. long, 2 ins. diameter in the middle of its length, and $1 \frac{5}{8}$ inch at the ends, is fixed in the centre ball or convex plate of the truck bolster, and the body bolster being turned right side upwards is placed thereon. The two trucks are now placed on a straight line of rails at the proper distance apart from each other for the intended length of wagon, Fig. 2, Plate 137, with their bolsters perfectly parallel to each other, so that the body bolsters in line with these are also truly parallel, and truly at right angles to the length of the wagon body to be erected upon them.

The tubes $T$ which form the sole-bars are of wrought-iron lapwelded, $2 \frac{1}{2}$ ins. inside diameter, 27 ins. outside, and $33 \mathrm{ft.} 2$ ins. long. When greater lengths are used, the tubes are welded together, 
as shown in Fig. 12, Plate 141, by providing a 7-inch length of double thick tube, $2 \frac{1}{2}$ ins. ontside diameter, and inserting this in the butt ends of the two tubes to be welded. For each wagon the tubes are eight in number, arranged in four pairs, Figs. 5 and 8 , Plate 139 ; each pair forms one sole-bar with one tube above the other, clamped at a distance of $6 \frac{7}{8}$ inches apart, centre to centre, Figs. 17 to 20, Plate 141. Four of the tubes are placed on the top of the pieces $\mathbf{F}$ attached to the body bolster, and four below. The ends of the tubes are adjusted to be truly parallel with the bolster; and the tubes are then fastened with clips $\mathrm{C}$ below and clips $\mathrm{D}$ above. The upper clips D are made with brackets on the top, Fig. 20, facing the longitudinal centre-line of the wagon; and upon these brackets are laid the longitudinal floor-stringers $\mathrm{S}$. The ends of the tubes, Fig. 13, are ready fitted with hexagonal-headed screwed-plugs, Figs. 14 to 16, which are now unscrewed, and a bolt $W$ is passed through each plug with the head inside, and is held in place by turning down with a hammer one of the three lips on the inside of the plug, Fig. 13. These bolts secure a malleable-iron casting to the ends of each pair of tubes, and a flat wrought-iron plate Y, Figs. 6 and 7, Plate 139, 4 ins. $\times \frac{5}{8}$ inch, is laid on the top of the castings, across the end of the wagon; another plate $Z$ of the same dimensions is placed beneath, being bent down in the centre so as to form the lower half of a hexagonal opening for the draw-bar to pass through; the upper half of the hexagonal opening is completed by a bent plate bolted upon the top of the lower plate. These two plates $\mathrm{Y}$ and $\mathrm{Z}$, lying parallel to each other, together form the headstock of the wagon. The external centre castings for the buffers are bolted on the headstock; and the wrought-iron links I forming the headstock truss are fixed in position, and drawn up tight by their end nuts, Fig. 7. The hexagonal opening in the lower plate $Z$ of the headstock receives the rests for the draw-frames A, Plate 138, which are placed in position between the headstock and the bolster, and are fastened at each end with strong bolts. The spring follower-plates $P$ are put in the rectangle of the draw-frames, and between the plates are interposed the draw and buffer springs. The draw-pin is inserted through the inside follower, the springs, and the outside follower, into the hollow draw-bar, which 
is itself inserted through the hexagonal opening lin the lower plate of the headstock; and the draw-pin is secured in the draw-bar by a strong cotter.

When the headstock at each end of the wagon has been built up in this manner, the two tubes in each pair are clamped together throughout the length of the wagon by webs and clips, which hold them as firmly as if in a vice, Figs. 17 to 20, Plate 141. The clips and webs are made with shoulders, Fig. 20, which rest against each other when they are bolted together, and hold them from slipping upon each other in any direction, so that the bolts are relieved from all transverse strain. The truss-rod struts U, Figs. 2 and 5, two to each pair of tubes, are at the same time clamped in their places on the tubes. The four longitudinal truss-rods $O$ are each divided in the middle of their length, and coupled by a screwed turnbuckle with right-and-left-handed threads, for screwing them up tight, Fig. 2. Bearing blocks for the truss-rods are fixed on the top of the bolster B, and the uncoupled rods having been passed through the headstock are bent over the bearing blocks and under the struts $U$, and coupled together in the centre by the turnbuckle, after a transverse bar of T iron has been bolted to the struts just above the rods, Fig. 5 . Transverse straining rods $\mathrm{N}$ are fixed obliquely between the upper end of the outside struts and the lower end of the inside struts, for the purpose of distributing to the outside sole-bars any excessive weight that may be placed on the inside sole-bars. The turnbuckle is screwed up so as to draw the truss-rods tight enough to bring the sole-bars up to a perfect level. The frame is now ready for the four Iongitudinal stringers $S$ of $2 \frac{1}{2} \times 2 \frac{1}{2}$ inches section, upon which is laid a floor of white oak $1 \frac{7}{8}$ inch thick. This completes the frame and floor for an ordinary flat wagon, the sides and ends above the floor being a matter of detail which can be varied to suit the requirements of the traffic.

The low-sided gondola wagon with drop ends, shown in Figs. 1 and 2, Plate 137, may be taken as an example. For fixing the sides of this wagon, oak stakes $V$ are used of $3 \frac{1}{2}$ ins. $\times 3$ ins. section and $2 \mathrm{ft.} 2 \mathrm{ins}$. high, which are fastened to the upper tube of the outside sole-bar by bolts and washer-plates 4 inches square, with two opposite 
corners turned in, Figs. 17 and 19, Plate 141. When the stakes are all put in place, two pine planks $2 \frac{1}{2}$ ins. thick by $7 \frac{1}{2}$ ins. wide and $33 \mathrm{ft}$. long, forming the sides of the wagon, are placed alongside the stakes and cold riveted to them. Flat anchor-irons, with $2 \frac{1}{2}$ ins. at the top bent at right angles to go over the sides, and at the bottom made round and screwed to pass through the floor, are fastened to the upper tube of the outer sole-bar by malleable-iron pieces $\mathbf{J}$, Fig. 5. The upper edge of the top plank is notched ont to receive the hooked end of the anchor-iron, and the latter is then passed through a hole made for the purpose in the floor, the piece $J$ is placed on it, and a nut underneath is screwed up as tightly as possible; after which the anchor is riveted to the sides with cold rivets and washers. The strap-iron coping, bored by templet for wood screws to pass through the hook of the anchor-irons, is fastened on the top of the side boards for their protection. The sides being thus completed, the drop ends are fixed by putting $2 \frac{1}{2}$-inch angle-iron anchors, with round screwed end, through the floor 3 inches from the inside ends of the sides; they are fastened the same as the side anchor-irons, the flanges being used to keep the end from falling outwards. Two planks $2 \frac{1}{2}$ ins. thick by $7 \frac{1}{2}$ ins. wide and $7 \mathrm{ft} .2$ ins. long are fastened together by two $\frac{1}{4} \times 2$ ins. straps, passing round the bottom and up both sides and cold riveted. Under the straps the end boards are notched out 4 ins. wide and 1 inch deep, to hold a link, the other end of which passes through an eye-bolt; the latter passes through the floor, and is held firm by a nut, thus forming a hinge upon which the end boards turn. The longitudinal truss-rods $O$ are now finally tightened up a little more, so as to give the body of the wagon a slight camber. With the exception of painting and oiling, the wagon is then complete and ready for service.

Bogie Trucks.--The four-wheel bogie under each end of the tubeframe wagon is of the kind known as the "diamond" truck, from the diamond shape of its two side-frames. It has now been in use more than forty years, and has never been found defective in any respect; it is therefore the standard truck on all American railways. For lightness, strength, and simplicity of construction, it has never been 
equalled. There is not a rivet in it to be cut off by vibration; and the bolts that hold the parts together are subjected to little or no strain. The construction is shown in Figs. 8, 10, and 11, Plates 139 and 140.

Instead of the horn-plates or axle-box guides of an English railway wagon, a pair of slide-columns L, Fig. 10, are bolted front and back on each end of a transverse oak spring-plank $Q$, which is 12 ins. wide by 5 ins. deep and $7 \mathrm{ft}$. 3 ins. long; each pair is fixed by four $\frac{5}{8}$-inch bolts, $14 \frac{1}{2}$ ins. long, of which the nuts and heads are alternately on opposite sides of the plank. Above the plank is an oak bolster $E$, of the same length and width but 8 ins. deep, sliding between the columns $\mathrm{L}$, between which it is guided at each end by a pair of slides fitting the columns and bolted on the bolster. Two pairs of wheels and axles are placed 5 feet apart, the axle-boxes are set on the journals, and the brasses or bearings placed in the boxes and secured with keys. Inverted-arch bars $G$ of best wrought-iron, $3 \frac{1}{2}$ ins. broad by 1 inch thick, are laid on the top of the axle-boxes, and bolts are placed temporarily in the outside holes to keep the wheels from spreading apart. The spring plank $Q$ is laid across the inverted-arch bars, midway between the wheels; two nests of bearing springs are placed on the top of the plank; and the bolster $\mathbf{E}$ is placed on the top of the springs. Each nest of springs is graduated, and contains one heavy and two light coils or spirals, the small springs to carry the body of the wagon and light loads, while the larger ones come into play for heavier loads. The temporary bolts are now removed, and a top arch-bar $\mathrm{H}$ of best wrought-iron, $3 \frac{1}{2}$ ins. by $1 \frac{1}{8}$ inch thick, is laid over the bolster, its ends resting on the ends of the invertedareh bar on the top of the axle-boxes. The slide-column bolts are put in place, and a bottom tie-bar $3 \frac{1}{2}$ ins. wide by $\frac{5}{8}$ inch thick is put under the axle-boxes and the inverted-arch bar, and is secured by the nuts on the bottom of the column bolts. The bolts fore and aft of each axle-box are put in through the two arch-bars above the box and through the tie-bar below, thereby securing the whole frame together, and keeping the axle-boxes in place. The bolster $\mathrm{E}$ is trussed by a pair of rods, bent under the central block beneath the bolster, and drawn up tight by a nut bearing against a washer plate on each end of the 
bolster, Figs. 8 and 11. The centre ball or convex plate of the balland-socket swivel-joint is fixed on the top of the bolster; and the side bearings $\mathrm{K}$, which are hollowed out to form oil cups, are placed in holes made for them in the bolster. The truck is then complete, ready for the brake hangings, as shown in Figs. 4 and 8; and the two trucks are made exactly alike, all their parts being interchangeable.

Wheels.-Whe truck wheels are made from a mixture of best charcoal iron and selected scrap, in the proportions required for ehilling; and are cast in metallic chills. When cool enough to be taken from the moulds, they are placed in a red-hot pit and covered up, and allowed eight to twelve days to cool. This extent of annealing renders them very tough. They are capable of standing at least the test of a weight of $140 \mathrm{lbs}$. falling 12 feet and striking centrally on the hub or boss four times, the flange of the wheel being placed downwards and resting upon three supports on an anvil block of 1,700 lbs. weight, which is set on rubble masonry 2 feet deep. When ready for the axle they are forced on it with a pressure not less than 35 tons and not exceeding 45 tons.

The average life of these chilled-tire cast-iron wheels is more than 120,000 miles, and the advantage they present over steel-tire wroughtiron wheels is fourfold:-they cost very uuch less, are 20 per cent. lighter, run a third further, and when worn out can be sold as scrap for 80 per cent. of their original cost. Their present cost at New York is $36 s$. each; and in replacing old wheels by new ones in the United States, the old wheel together with $6 s$. will buy a new one. The steel-tire wrought-iron wheel after running about 22,000 miles has for safety to be turned up, which process it will stand three times, giving a total of about 90,000 miles. The flanges soon get rough and torn, and too thin and sharp for safety; whereas those of the cast-iron wheels soon become smooth and highly polished, the chilled iron being much harder than steel. When no longer fit for service, the value of the steel-tire wrought-iron wheels must be little enough, judging from the numbers of them that are to be seen lying on the scrap heaps of the railways on which they have been used. Expexience 
on the Belgian State Railways with the tube-frame wagon has shown that the standard steel-tire wrought-iron wheels there adopted will not stand under the heary loads intended to be carried on the same wagon with chilled-tire cast-iron wheels; they have recently broken down under a load of 35 tons.

Axles.-The truck axles, Fig. 8, Plate 139, are 5 ins. diameter through the wheel boss, and $4 \frac{1}{2}$ ins. in the centre, with journals 4 ins. $\times 7$ ins. They stand without fracture three blows with 12 feet fall, followed by two blows with 18 feet fall, of a weight of 1,640 lbs. striking midway between supports 3 feet apart, the axle being turned over after each blow.

Brakes.-The brakes used are known as "inside hanging brakes," Figs. 4 and 8, Plates 138 and 139. The brake blocks holding the brake shoes are attached to the ends of a transverse beam, which hangs suspended by links from the truck bolster, and carries the brake-lever fulcrum in the middle of its length. The short ends of the pair of levers are coupled by the bottom tie-bar. The top of the inner lever rests in a forked guide-plate with graduated pin-holes, and the top of the outer lever rests on a round-iron guide. A chain attached to the top of the outer lever leads thence to the brake shaft, round which its other end is wound. This shaft is provided with ratchet-gear, which is worked by the foot to hold the brake in place. The levers ean be worked by hand, or by any system of air or vacuum brake, or with side levers if necessary.

Strength of Wagon.-The tube-frame wagon with its two bogie trucks and chilled-tire cast-iron wheels has a breaking strength of 300 tons. A good illustration of its strength is furnished by the use of 112 of these wagons in April 1888 for moving back the Brighton Beach Hotel at Coney Island, New York, a total weight of more than 6,000 tons. After 24 tracks had been laid in the sea, and the 112 wagons had been placed in position upon them under the hotel, and the weight of the load brought to bear upon the wagons, there occurred a great storm lasting from 12th to 
15th March, which so delayed the work of extending the lines in the rear of the hotel that the wagons had to continue supporting its entire weight for more than six weeks. After it had been moved inland through the required distance of 595 feet, none of the wagons showed any sign of being overstrained, though some of them had been carrying loads exceeding 120 tons. At the finish there was not a timber or board of the hotel broken, nor a crack or opening in any of the joints or angles of the building, nor had a pane of glass or a chandelier been injured, so uniformly had the wagons stood up to their work. In its new site this large hotel is therefore a standing witness to the excellence and efficiency of the tube-frame wagons. The identical wagons which were employed on this work have been in service ever since, carrying daily loads of 30 to 35 tons, without costing anything for repairs other than re-painting.

Flexibility.-When the line is uneven, the rigid and cumbersome wagons used on English railways sometimes stand on three wheels only, the fourth being held up above the depression in the rail by the rigidity of the frame. The same is the case with bogie trucks having rigid frames; and for this reason, together with the excessive cost for repairs, the use of rigid square or rectangular frames for the bogie trucks of goods wagons has been abandoned in America, and the flexible diamond-frame truck has been adopted instead. This truck can run round a curve, of which the radius is equal to the square of its wheel-base; and in a properly constructed truck the wheel-base should be the same as the gauge. Thus on the $4 \mathrm{ft}$. $8 \frac{1}{2}$ ins. gauge the diamond truck can run round a curve of $22 \mathrm{ft}$. radius. Two wagons rounding a curve of $55 \mathrm{ft}$. radius are shown in Fig. 9, Plate 140. Prior to actual trial of bogie trucks, it has sometimes been erroneously supposed they will never do for the goods traffic on English railways, in consequence of the speed that is required in this country. In running round any curve there is always a lateral pressure of the wheel flanges against the outer rail, proportionate to the momentum of the wagon and its load. But with a bogie truck at each end, the weight of the wagon body and its load rests upon the ball-and- 
socket bearing in the centre of the truck, so that the wheels have free play to adjust themselves to the curve, and can more easily run over any obstacle or unevenness in the rails, without imparting the jolt to the body of the wagon and its load. This is the reason why a locomotive can take a train of 40 tube-frame bogie wagons loaded with 30 tons each as easily as a train of 32 ordinary English wagons loaded with only 8 tons each. Both the inertia of the train and the resistance it encounters from the road are more easily overeome with bogie trucks than with four-wheel wagons having no radial axles. As an evidence of durability, a photograph is shown of several diamond-frame trucks that were washed $4 \frac{1}{2}$ miles down the bed of the Junietta river at the time of the Johnstown flood of 1st June 1889 ; and when taken out they were put in service again at a very small expense, the principal loss being the wooden floors and sides and one third of the original cost of the tubes.

In commenting upon the construction of the long tube-frame bogie wagons, a German engineer, Mr. Henri Macco, who is one of the directors of the German State Railways, has recently remarked that in building new goods wagons the object should be to increase their carrying capacity and diminish their tare weight; but the realisation of this aim is limited with the present build on account of the rigid wheel-base. The longer the wagons, the further apart must the axles be ; the greater will then be the resistance in running round curves, and the larger the expenditure for locomotive power and for maintenance of rolling stock and permanent way. With a bogie truck at each end he points out that the length of the wagon is quite independent of the distance between the axles in the truck, as well as of the sharpness of the curves. It is by means of the bogie trucks that the American railways have been able to increase the paying load of their goods wagons to 20 and 30 tons; and there is the prospect of its being further increased before long to 40 tons. The weight of the tube-frame wagons of 34 feet length which are now running on the Furness Railway is 8.3 tons, and the load they carry is 30 tons; while the ordinary wagons in use on that railway weigh 6 tons and carry 8 tons, their length varying from 18 to 20 feet. 
Maintenance and Repairs. - The only expense required for maintenance is the renewal of brasses, and re-painting every second year.

From the manner of bnilding the wagons it will be seen that there is little or nothing to get out of order or to repair. All ordinary repairs can be made in a few minutes, while the wagon is loaded and standing in the train. If a bearing is to be examined, the axle-box can be lifted an inch by a lever or jack placed under it, the key and bearing taken out, and the latter if necessary replaced by a new one, in less than five minutes. If a pair of wheels is to be taken out, a jack should be placed on each side of the truck under the bolster column, and the truck raised sufficiently to ease the wheels; the outer bolts are removed, and the nuts of the inner bolts loosened; the wheels and axle can then be pushed out by pressing the boxes outwards with the foot, and a new pair of wheels put in; with new wheels and axle at hand, the whole process requires less than fifteen minutes. If any of the struts, straining rods, or malleable castings should be broken, which however has never yet occurred even in a wreck, they are all numbered and could be telegraphed for, or could be taken off from another trbe-frame wagon, if an empty one happened to be on a siding near by, as all parts are interchangeable.

An illustration of total wreck is furnished by one of the photographs exhibited. In this case the woodwork above the tubeframes was a total loss. The badly bent tubes were taken back by the tube makers, and new tubes were delivered at one-third of the original cost. The castings were not injured, and 98 per cent. of them were used in building new frames. In another instance one of the low-sided gondola wagons that was loaded with 30 tons of pigiron got off the rails, and ran over the sleepers for about its own length, springing up and down in! the middle as it went over each sleeper. Instend of the tubes being twisted out of shape, as might have been expected, and the wagon otherwise badly injured, it was found to have sustained no damage whatever. This may be considered one of the severest tests that any wagon could pass through without damage; and it may be doubted whether any other wagon could have stood it, loaded as this one was. Immediately after the accident the 
same wagon was sent a distance of 1,800 miles with 27 tons of castings, and has been in active service ever since.

Railway Working Expenses and Goods Rates.-According to the facilities and cheapness of transport by rail in other countries will their surplus products be pressed upon Great Britain. At the present time for every hundred tons of grain he sends to London a farmer living 1,000 miles inland in the United States has an advantage of £30, after paying both land and ocean transit, over a farmer living at Stirling in Scotland, only 420 miles from London. Why should railway rates be so much lower in America than in England? The answer sometimes given is because the English railways have cost nearly three times as much to make as the American. Although this is very true so far as it goes, it is no reason why the haulage of goods should cost the English railways three times as much as it costs the American. If it costs more on a good line than on a bad one, why have the better line?

In 1889 the average rate charged for all descriptions of goods on all the railways in the United States, including terminal charges, was only 0.488 penny per ton per mile, while the average cost to the railways was only $0 \cdot 311$ penny. The average dividend on highly inflated shares was $3 \cdot 3$ per cent. The average earnings and working expenses of the three best lines in America, or those that compare most favourably in construction with the English railways, are as follows :-

\begin{tabular}{|c|c|c|c|}
\hline & $\begin{array}{c}\text { New York } \\
\text { Central. }\end{array}$ & Pennsylvania. & $\begin{array}{l}\text { Philadelphia } \\
\text { and Erie. }\end{array}$ \\
\hline Eamings per ton per mile & . $0.38 d$ & $0 \cdot 313 d$ & $0.278 d$ \\
\hline Working expenses per ton per mile & $\theta \quad 0.28 d$. & $0.201 d$ & $0 \cdot 176 d$ \\
\hline Annual earnings of each locomotive & e $£ 7,200$ & $£ 7,610$ & $£ 7,000$ \\
\hline Dividends per cent. & $4 \frac{1}{2} \%$ & $5 \%$ & $5 \%$ \\
\hline
\end{tabular}

Compared with these, the London and North-Western average earnings are estimated at 1.25 penny per ton per mile, with a cost of 52 per cent. or 0.65 penny per ton per mile for working expenses, while the average earnings of each locomotive in 1888 were only $£ 4,100$. The average annual earnings of each locomotive in 1889 on all American railways, good bad and indifferent, were $£ 6,590$; 
while the average annual earnings of each locomotive on all the railways in the United Kingdom were only $£ 4,837$.

Since 1865 the railway rates in the United States have been reduced fully 79 per cent., so that the railways are now rendering for $£ 21$ the same service for which in 1865 they charged $£ 100$. The reason they have been able to make so great a reduction is that they have gradually improved their goods wagons, which would formerly carry loads of their own weight only, until they will now carry three or four times as much. Within the past ten years the Pennsylvania Railway has changed nearly its entire goods rolling stock from wagons that weighed 10 tons and would carry only 12 tons to wagons of the same dead weight which will now carry a load of 30 tons and even up to 40 tons. The strong competition of navigation on the rivers and lakes, and on canals constructed at the public expense, has stimulated railway ingenuity to the utmost in America; and even with the low rate of working expenses which has already been reached it is not considered that the minimum has yet been attained. On the English railways during the past thirty years neither have the goods rates undergone any reduction, nor have the working expenses been lessened so that the rates could be lowered and still yield fair profits. As to the opportunities there are likely to be in this country for loading fully the larger wagons such as are running on the American lines, it must be borne in mind that 72 per cent. of the freight traffic on English railways consists of coal and other minerals, which are carried in full wagon loads at the present time. The proportion of coal and other minerals to the total freight carried on English railways is much greater than on American lines. Thus the freight traffic on the Great Western Railway in 1888 was 75 per cent. minerals and 25 per cent. general merchandise; while that on the New York Central in 1889 was only 30 per cent. minerals to 70 per cent. general merchandise. The traffic of the latter railway is carried wholly in large bogie wagons.

One of the great objections sometimes urged to the use of long wagons on English railways is that the turntables are not large enough. In America turntables are never used for wagons. The bogie trucks permit of using curves of one chain or 66 feet radius, 
whereby a whole train of wagons can be shunted by a locomotive on a right-angle siding in less time than four or five men with a horise could turn two short wagons on a turntable. Another opjection occasionally made to the bogie wagons is that they are too long for the present weigh-bridges. Most of the weigh-bridges in the United States are made for wagons 32 feet long; but there are hundreds of wagons 40 feet in length that pass over them and are weighed daily, one end at a time. It certainly requires less time and expense to weigh one wagon with 32 tons load by weighing one end at a time, than to weigh four wagons of 8 tons each. The centre of gravity of any load cannot be changed without taking off or adding to some portion of the load itself; and the sum of the two weighings of the long wagon, one end at a time, is the same as if the whole wagon were weighed at once on a weigh-bridge long enough for the purpose. Thus two of the principal objections to the long wagons can be overcome by doing the work in the simplest, cheapest, and most expeditious manner. New weigh-bridges are continually being bought; and as a 50-ton weigh-bridge 32 feet long can be purchased at less than $£ 150$, the expenditure sinks into insignificance when compared with the saving it will effect.

On the railways in the United Kingdom there are now about a million wagons, with an average carrying capacity of 7 tons each; and for renewals and extensions about 100,000 are added annually, costing an average of about $£ 60$ each, or a total of $£ 6,000,000$. Were the tube-frame wagons adopted to the extent only of this yearly addition of carrying capacity, and used in places where they could get full loads, the change could be effected without any strain upon the finances of the railways, as only 24,000 of them, costing an average of $£ 165$ each or $£ 3,960,000$ altogether, would be required to carry the same tonnage, being $£ 2,040,000$ less than the railways are now expending. The benefits derived from the lightness and flexibility of the new rolling stock would tell so greatly upon the profits that the present rigid four-wheeled wagons would soon be entirely discarded. The cheapest goods traffic in the world is at the present time being carried on by means of these tube-frame wagons, whereby the yearly saving in working expenses is more than 
equal to the annual dividend on any railway using them; and no line can compete for traffic with a rich rival, unless it secures for itself the powerful aid derived from the ability to carry heavy loads in light wagons, as against light loads in heavy wagons.

\section{Discussion.}

Mr. JeFFERDs exhibited a number of photographs of the tube-frame wagons, showing the adaptation of this method of construction to high-side and low-side goods wagons, hopper coal wagons, and various other kinds of wagons in ordinary use; and showing also the nature of the injuries sustained by these wagons in accidents. $\mathrm{He}$ also showed specimens of the tubes and clamps, and of the weld made in joining two lengths of tube together. The principal feature in the tube-frame combination, he pointed out, was the mode of clamping the tubes together in pairs, the clamps being made of malleable cast-iron, which had a tensile strength of 50,000 lbs. per square inch, and could be bent over to a right angle without fracture, and twisted round to a considerable extent without breaking. The bolts and nuts holding these clips together were not subject to any transverse strain whatever, all such strains being prevented by the shoulders upon the clips themselves.

Mr. W. A. Adams understood one object of the paper to be to illustrate the fact that in England far more dead weight than paying load was carried. In 1876 he had himself read a paper before the Institution of Civil Engineers (vol. xlvi, page 100), in which he had dealt very fully with this subject, and had illustrated it at great length by the practice of English, French, and American railways. Since that time the Americans had advanced very much in the reduction of dead load, or rather in the increase of paying load. In this respect the French had been much in advance of the English at 
that time: the goods traffic on the Western Railway of France was conveyed in high-side wagons holding 10 tons, and weighing only $3 \cdot 45$ tons, notwithstanding that they were fitted with buffer springs and buffer rods, which of course increased their weight. In the present paper it was represented that by the use of bogies the wagons could be much improved with respect to the ratio of the paying weight to the dead load; and that there was a much greater advantage in using tube frames than in using frames of wood flitched with iron. The English practice was to carry the wagons on four wheels; the American practice was to carry them on two bogies with four wheels each. The question however of the load carried in a wagon.was not whether there should be eight wheels on the bogie principle or four wheels on the English plan; the question was, what should be the load upon each wheel. On a good road he considered that the cost of traction per ton was the same for a fourwheeled wagon as for an eight-wheeled. Supposing the load per wheel to be three tons, the former would carry twelve tons and the latter twenty-four. In the four-wheeled wagon the wheel base would have to be 9 feet, and in the two bogie trucks of the eight-wheeled wagon it would be about $4 \mathrm{ft} .8$ ins. There had lately been some extraordinary letters in the daily papers with reference to the low cost at which freight was conveyed in the United States, in consequence, as it was said, of the use of bogie wagons; reference was not made to tube-frame wagons, the question being whether the load was carried on a four-wheeled wagon or on eight-wheeled trucks. It was stated in the paper (page 485) that on the Furness Railway the ordinary wagons weighed 6 tons and carried a load of 8 tons; he could only say that such a proportion would reflect upon the designer and the constructor. The reason why in England the road was overloaded and the wagons made heavier than they otherwise need be, he imagined was that the object desired was to reduce the cost of repairs-not of construction, because the heavier the wagon, the more material it took, and the more its construction must cost. If a coachmaker were asked to build a landau and to make the felloes and the frame and body of a lighter section than usual, be would probably object that the carriage would wear out 
(Mr. W. A. Adams.)

much faster and would be oftener in for repairs. To which the reply would be that the repairs of a landau did not cost nearly so much as horses and their keep. It was the same with a railway: something might be saved in repairs by heavier construction, but at the expense of locomotive power. If the conditions for traffic in England were the same as in America, two English four-wheeled wagons could be constructed to carry 24 tons as readily as an American wagon would carry 24 tons. He did not see what there was in the bogie truck that should diminish the traction. If it were urged, why then did the Americans prefer to convey traffic on bogies? the answer was that, in the commencement of railways in America, the roads were so bad that they could scarcely indeed be called roads; they were mere tracks. Ditches were cut along each side, and the stuff was thrown on the middle of the track, upon which the light sleepers and rails were laid. On such a road the traffic of English wagons and locomotives could not be carried. Two small short bogies were therefore constructed, with small wheels from 18 to 24 inches diameter, upon which was placed a body, and with that vehicle a load was carried of 6 to 8 tons. Those bogies, low-wheeled and short, wobbled in and out as they ran along the road, and just managed to get along with their load. Such an insufficient contrivance was a necessity in the early days of American railways, in order to get through the work; but the English railways were different. The American construction of railways having once been set, and bogies started upon them, the plan had been persevered in, and it had now become difficult to get out of the groove. If he were called upon to construct a railway for opening up a new country, like central Africa, he should certainly begin as the Americans had done, and throw the stuff from the ditches on the centre of the road, and lay upon it a track of 2 or 3 feet gange, on which he should put two light bogies with a body of some sort, and a light engine that could just get along, the whole construction being extremely small and cheap. But as the traffic grew, he should abandon that type at an early stage and resort to the English plan.

Although some allusion had been made in the paper to the question of how these long bogie wagons were to be dealt with in England, he did not think that all the difficulties had been 
weighed. In the first place, it should be borne in mind that in England outside buffing could not be done away with; and with outside buffing it would be impossible for the wagons to work round a curve like that shown in Fig. 9, Plate 140, of 55 feet radius. In America such curves were managed only by having all the buffing nearly central, as well as the traction. Then again there was the question of the turntables. If one of these eight-wheel bogie-wagons were running in North Wales, round short curves and up and down hill, what convenience would there be for loading and working? It would be singularly inconvenient. He did not know what the practice now was in Pennsylvania and in New Jersey, but he knew what it used to be. A large amount of the coal traffic of those countries used to be carried in four-wheeled wagons, which were almost the counterpart of the old wagons on the Taff Vale Railway, because it had been found that the eight-wheel bogie-wagons were not suitable for a billy and difficult country like those. In page 485 of the paper there occurred what to him was an extraordinary statement, that 40 tubenframe bogie-wagons loaded with 1,200 tons altogether could be drawn with no more locomotive power than 256 tons of load carried in 32 English four-wheeled wagons. This seemed to him so amazing that unless it was backed up by actual facts he certainly thought there must be some error. With the remark in page 488 he quite agreed, that ten years ago the goods traffic on the Pennsylvania Railway used to be conveyed in wagons weighing 10 tons and carrying only 12 tons. It should be borne in mind that in those days the Penusylvania Railway branches--not the main line itself--were inferior; and therefore the new wagons carrying 24 tons, built for good roads having runs of 2,000 and 3,000 miles, could not work upon those inferior branches. If there were the same conditions of traffic in England as in America, one of those long wagons would be loaded at 2,000 or 3,000 miles from the port with 24 tons or more, and would be coupled in a long train, and taken along a road with the easiest of gradients and curves. In America such a train was drawn by what was called a "consolidation" engine, which had eight coupled wheels, and a two-wheeled pony truck in front. Any road that would carry those engines, which 
(Mr. W. A. Adams.)

conducted the chief through freight of America, would readily enough carry a four-wheeled wagon with 9 feet wheel-base.

Mr. Bernard Dawson asked whether some of the difficulties of using these long wagons on English lines had been sufficiently considered. Taking the traffic of a small road-side station, there might each morning be as many as four or five wagons from London. Manchester, Liverpool, or other large stations, as well as wagons with coal and lime and other undamageable goods; and if there were to be none but these long wagons, containing perhaps only from 2 tons to 5 tons each, the sidings would have to be considerably extended in order to receive five or six different consigmments. There would also be some difficulty in dealing with the wagons in the hydraulic hoists in large goods stations, where there were three or four tiers of floors; and great expense would be involved at some stations, as at some of the London termini, at Manchester, at Edgehill, and places of that kind. Some idea he hoped would be given of the cost of maintenance of these wagons on the Furness Railway, and also as to what they were principally loaded with. The two entire truckload freights going any real distance on the Furness line were the iron ore from the mines to the blast-furnaces, and the pig-iron from the Barrow and Ulverston district to Sheffield. He should be glad to know whether the long wagons were used for station to station traffic, or whether only for undamageable iron, or whether also for goods that required to be protected with tarpaulin sheets; and how it was proposed to deal with the trans-shipment of the loads at junctions, and with small consignments. The average loads of light damageable goods on English railways he believed did not exceed 7 or 8 cwts. It would be a serious thing to have to use wagons 32 feet long for taking loads of even $30 \mathrm{cwts}$. of sheeted goods. He did not know whether the American railways were covered with facing points, sidings, and locking bars; but he certainly did not see how the traffic of crowded station-yards, with facing points and gridiron sidings like those at Edgehill, could be worked with wagons 32 feet long. It would necessitate a re-arrangement of most of the large goods yards to accommodate wagons of that length, however short might be the wheel-base of the bogies. 
Mr. WILLIAM Evans, general manager of the Cyfarthfa Iron and Steel Works, thought it would be advantageous to the freighters in South Wales to have wagons carrying much larger quantities than the existing wagons could carry. For carrying iron ore and other materials for the supply of blast-furnaces, he thought there was one deficiency in the construction of the larger wagon described in the paper. For instance, where there existed overhead gantries with sufficient depth or capacity underneath for holding a quantity ranging from 30,000 to 40,000 tons of materials for the furnaces, it was highly necessary that such a wagon should be made with a bunker bottom, so as to discharge its contents below, without the excessive manual labour at present required. Looking at the larger wagons from the freighter's point of view, he was of opinion that they would be very beneficial.

Mr. Edward H. Carbutr, Past-President, hoped that those members of the Institution who were at the present time visiting America were making it their business to enquire into the conduct of railway traffic, and the reason why it was there conducted so cheaply. To his mind it was lamentable that during the last two or three years the representations made by the public and by the railway authorities in the discussion before the Board of Trade in regard to railway rates had been so seriously conflicting. That discussion he believed had been a most expensive one, having cost a large amount of money not only to the government, but also to the freighters of the country, who had had to engage barristers to conduct their case. It had also cost the railways themselves a great deal, because during the whole time that the discussion was going on most of their general managers and most of their lawyers had to be in attendance; and the consequence had been that this portion of the talent of the country, instead of being directed to the saving of expense, had been largely engaged in incurring expense for the railways, which would have to be borne by the public in future. It would have been much better he thought if the large sum which the Board of Trade enquiry had cost had been spent in experimonts to ascertain whether railway traffic could not be carried more cheaply than at present. If 
(Mr. Edward H. Carbutt.)

the public would bear in mind that they were partners with the railways, and if the railway companies would equally bear in mind that they were in partnership with the public, it would be possible to conduct their traffic much more cheaply than hitherto. A future date he hoped would witness much more extensive amalgamation of railway companies than had hitherto taken place, so that the railways would be in fewer hands than at the present time. A sliding scale would then be required, as in the case of gas works, so that when the railways paid a larger dividend they wonld be obliged to reduce their rates. The railways would then be directing their attention more and more towards conducting the traffic at a cheaper rate than they did at the present time.

The use of bogie trucks was simply a question of the exigencies of the traffic, as pointed out by Mr. Adams (page 492). The bogie trucks had been in use for some years under the long passenger carriages on the Midland Railway and other lines in this country, and their value was well known. The main feature of the long wagons described in the paper, as he understood, was that the sole-bars were made of tubes. But with regard to the extraordinary statements made as to the American mode of carrying traffic in contrast with the English mode, he for one should be loth to accept them as all perfectly true. The worst case in English practice appeared to be contrasted with the best in American. One of the reasons already alluded to (page 493) why traffic could be carried more cheaply in America was that their wagons had no outside buffers, thereby reducing the friction; but in England it was found necessary to have buffers. The English wagons involved a certain amount of friction; and if these long bogiewagons were substituted, it would be found that the friction was still as great as at present, and greater than it would be if the shorter wagons had their wheels loose on the axles. His impression was that the time would come when it would be necessary to go in for wheels loose on the axles, so as to allow each wheel to revolve independently on its own account when going round a curve. Some years ago he had devoted a good deal of attention to this subject, and several wagons had been running on the Great Northern Railway for eight or nine years with the Miltimore 
arrangement of wheels loose on their axles.* The principle of loose wheels he believed would be found to be the solution of the difficulty; but whether it was or not, he thought that, if the railways would spend some of their money in helping this Institution to carry out certain experiments with regard to traction, it would be a great advantage to the country at large; for a great many more experiments than had at present been tried were needed to settle such questions.

But he doubted whether the English railways would go in for longer wagons. Taking the case of the coal traffic into London, great difficulties would be experienced with longer wagons, because the present short wagons were obliged to be employed for shunting into the different drops, and for the different kinds of coal. Moreover,

* The Miltimore axle with loose wheels is shown in Plate 146. A pedestal block $\mathrm{P}$ carrying the weight of the vehicle is keyed upon each end of the plain cylindrical axle A, which is thus held from turning. Round the axle revolves a tubular wrought-iron sleeve $\mathbf{S}$, on which is fixed at each end a castiron socket $\mathbf{C}$; and inside each socket is fitted a cylindrical brass bush $\mathbf{B}$, fitting the axle $\mathbf{A}$, round which it revolves, while the sleeve itself nowhere tonches the axle. The ontside of the cast-iron socket $\mathrm{C}$ is turned to form the wheel seat, on which the wheel hub W is mounted loose, being held in place on the inside by the shoulder of the socket, and on the outside by a nut I screwed on the end of the socket and fitting into a recess turned in the hub. The bearing is lubricated with oil or grease from a chamber $M$ in the pedestal block $P$, through a central longitudinal passage in the axle and down through a vertical passage to the bearing surface, which in this construction is on the under side of the axle. The outside of the brass bush $B$ fits into the socket $C$ with a surface rounded spherically, so as to allow a very slight oscillation in any direction, for enabling the bush to conform freely to the spring of the axle, thereby ensuring a perfect bearing throughout the whole length of the bush, and preventing undue wear at its ends. When running on a straight line, the wheels though loose on the sleeve carry it round with them, owing to the greater friction between the wheel hub and its seat than betwen the bush and axle. But whenever from any cause one wheel has to run faster than the other, either wheel is free to slip round on its seat, independent of the other, and without interfering with the revolution of the sleeve round the axle. The wheel seat is lubricated through a slot cut longitudinally across the thread on which the nut $I$ is screwed to the socket $C$; and from the oil leaving the outer end of the bush $B$ an ample supply is carried by centrifugal motion over the inner face of the nut to the slot, and forced through it to the wheel seat. 
(Mr. Edward H. Carbutt.)

as already pointed out (page 494), it would be found that there was only a small amount of traffic between intermediate stations, while the number of stations to be served was great, owing to the thickly populated country; and the result was that there was never any such long heavy haulage here as there was in America. It had been stated (page 487) that corn could be brought from places a thousand miles inland in America, then over the sea, and delivered in London, cheaper than it could be delivered from Scotland. At the present moment however not a penny had to be paid for bringing corn from America, because the ship-owners were glad enough to bring it for nothing as ballast. It was difficult to find out all the truth as to the cost of carriage, and he was glad that the question had been opened up by the present paper; but his own impression was that the railways of this country would not find it to their advantage to adopt large wagons. Years ago the Great Western Railway had had much larger wagons than they now used, and they had found it to their advantage to make the change to the present smaller size. When they had larger wagons, it was not a paying line; but now that they had smaller wagons, suitable for the traffic, they were paying much larger dividends than before.

Mr. EDWARD JACKson said that, although as a rolling-stock manufacturer he should be happy to make any wagons which the railways might decide to adopt, yet he saw many difficulties, such as had already been pointed out, in the way of working the traffic in England with these large wagons, which would be awkward to deal with in the conveyance of coal and minerals, wherever they had to be unloaded quickly. The first cost of such wagons he imagined would be little, compared with the cost of renewing the material from time to time. The question was one for the railways rather than for the wagon builders.

Mr. J. H. WATSON, regarding the question from a commercial and economical point of view, had endeavoured twenty-five years ago to show how the railways could carry the greatest paying weight in proportion to the dead weight. An important step in this direction 
had been taken on the Midland Railway in 1874, when the number of classes in passenger trains was reduced from three to two, whereby a great saving had been effected. Being himself a large contributor to the traffic of the railways in this country by sending goods over their lines, he strongly objected to paying double rates in England if the same service could be done for half the money, as it was in America. Although he had never been in America, he knew that on the canals there was a good deal of competition with the railways, and that formerly minerals and similar traffic used to be carried by water, but now with these long and improved cars the railways had obtained the traffic and beaten the water-carriage, being able to do the work cheaper in consequence of their paying weight being so largely increased. The question of railway rates was indeed a most serions one for this country, especially for manufacturers, merchants, farmers, and consumers; because, if the present high rates were kept up, they would drive the trade out of England for the benefit of foreign rivals.

Mr. Jamms Conqunoun, general manager of the Tredegar Iron Coal and Steel Works, said this subject was a most interesting one to all who were connected with South Wales. With their present rolling stock the adoption of the long American wagons would involve expensive alterations. The first consideration was the saving in carrying a load of 30 tons in a truck weighing only 10 tons, as compared with carrying 10 tons load in a truck weighing 5 tons. No doubt the expense would be great of altering the sidings, turntables, weighing machines, hydraulic lifts, and many other existing appliances, to suit the longer wagons; but if it could be proved that their use would effect a largely remunerative saving over the present short wagons, the matter was certainly worthy of serious consideration.

Mr. G. E. Church mentioned that there were some six thousand of these tube-frame cars now in active employment in the United States, and many more were being built; the builders had more orders than they could fulfil without enploying other works, and 
(Mr. G. E. Church.)

did not now build them except for leasing to the various railways, because they found this the more profitable method. With regard to the bogie truck, it had been stated by Mr. Adams (page 492) that a four-wheeled wagon with rigid wheel-base would take the load over a line as easily as a bogie truck. But if in a landau or brougham the forward wheels were rigidly fastened so that they could not swivel, and an attempt were then made to turn a corner at the rate of eight miles an hour, the difference between a bogie and a rigid wheel-base would be appreciated. Having himself sent five of the tube-frame cars to a railway in the Argentine Republic, he considered their carrying capacity quite secondary to their remarkable elasticity, which enabled them to take up and distribute every motion with the least shock, and consequently with the least wear and tear to the vehicles themselves and to the track on which they ran.

Mr. C. W. Radsor gathered from the paper that one of the merits of the tube-frame bogie wagon was the facility with which it could be repaired or rebuilt after it had been thrown off the line. This might constitute a merit on American railways; but on English railways accidents were so much more exceptional, that facility of re-building a wagon after it had been thrown off the line was not regarded as any merit at all.

Mr. J. J. Sмiтн was surprised to hear Mr. Carbutt say (page 498) that the Great Western Railway had found it to their interest to reduce the size of their wagons. Having been interested as a freighter on that railway for the last twenty-five years, he was not aware that, apart from the conversion of broad gauge to narrow gauge, the tonnage of the wagons had been reduced.

Mr. Josepr SANDens considered that the prosperity of the country largely depended upon cheaper railway rates. By means of these tube-frame wagons the paper had shown that the American railways could carry twice as much load in proportion to the dead weight, for a 9-ton car could carry a load of 30 tons. In order to prevent skidding in running round curves, it had been proposed (page 496) 
to have loose wheels. Instead of these however, he had himself devised a plan of dividing the axle in the middle of its length, and providing a centre bearing for the inner ends of the two half lengths, so that the wheels while still fixed on the axle could nevertheless run quite independently of each other when going round a curve, and all torsional strain upon the axles was done away with. In this way he believed the friction of the rolling stock would be reduced, to much below what it was at present in the absence of any such provision.

Mr. J. C. TaITE mentioned that at the Leeds Forge a considerable amount of attention had been given to the subject of reducing the dead weight of railway wagons; and he thought it was quite possible that this object could be accomplished by means of steel underframes shaped by hydraulic pressure, without the necessity for adopting the long wagons described in the paper, which appeared to offer so many difficnlties for English railways. The pressed-steel frames gave an economy of 30 per cent. in weight, as compared with the replaced parts of a wooden underframe to carry the same load; and of 20 per cent., as compared with the lightest form of channel-iron underframe used on English railways. For the London and South Western Railway a large number of bogies had been constructed with pressed-steel frames. Little had as yet been done in England with these bogies for wagons, but they had been used more for carriages. For foreign railways a large number had already been made; and if the diamond bogie was as great a success in America as it was represented to be, it might be pointed out that with the pressed-steel frames a bogie could be made quite as light and quite as strong, and even cheaper. In a short period he did not doubt that wagons manufactured by English makers would be running on the lines in this country, not only of a lighter build but also carrying a heavier load than at present.

Mr. Wir.ram Marriots said it appeared to be thought that nothing had been done on English railways with regard to reducing the dead weight of wagons; but ho knew as a fact, although it had 
(Mr. William Marriott.)

not been mentioned, that several of the new wagons described in the paper were now being tried in England. The chairman of the Eastern and Midlands Railway, who was also interested in a railway which carried in bulk-and after all the question was mainly one of carriage in bulk-had thought he should like to order half-adozen of the long tube-frame wagons for a trial. The traffic to be delivered was China clay in 30-ton lots. A difficulty however was experienced. The line of railway ran parallel to the shipping quay, and the present short trucks laden with clay were turned on small turntables to run down on to the piers into deep water. The long trucks would have been ordered, but for that difficulty. The turntables and the quay belonged to another railway, over which he had no control. That was an instance showing the difficulties with which the railways were beset. He had himself been much interested in this subject for a long time; but the Eastern and Midlands Railway, which he represented, was only a short line, and did not carry traffic in bulk. He agreed with Mr. Dawson (page 494) that a 2-ton load was perhaps the maximum, except in the case of coal and grain. At any rate it might be taken that coal and grain were the only two articles carried in sufficient bulk to render a long wagon like that described in the paper at all economical. He had himself been obliged to reduce the size of his wagons as much as possible, in order to reduce their dead weight. A great deal of the traffic was from other railways, whose wagons were consequently employed for it; but the Iocal agricultural traffic was nearly all in light loads. The size of wagon to be adopted depended largely upon what was the bulk in which the traffic could be carried. In England nothing like the bulk was carried that was carried in America. Perhaps almost the only things that could be carried in bulk in this country were coal, iron ore, limestone, and grain. Reference had been made to the alterations of weigh-bridges, hydraulic stations, lifts, and turntables, which would be requisite if long wagons were adopted. In America, where there was plenty of land to be had for the purpose, triangles could be used instead of turntables; but in England as a rule there was not land enough to be got, and therefore turntables had to be put in so as to avoid triangles. 
Mr. L. Stenve observed that the discussion had thus far turned altogether upon the use of bogies and the length of the wagons, and not at all upon the construction of the tube-frames, for which be noticed that iron tubes were employed. As already mentioned (page 501), Mr. Samson Fox had turned his attention to hydraulic forging as a means of making steel underframes for railway wagons. In this direction he had already done good work; and he believed he was now domesticating his method in America. But he was not making steel frames of such length as the long tube-frames described in the paper. Those tube-frames he thought might be made shorter to suit the length of the ordinary four-wheeled wagons. There was no reason that he could see why the tube-frame wagons should not be made as short as the ordinary four-wheeled wagons in use in Great Britain ; and there was no mechanical difficulty that he could see to prevent this being done. Why the inventors should increase their difficulties by endeavouring to introduce tube-frame wagons of so much greater length than in use here he could not understand. If railway engineers and superintendents could see their way to reduce expenses in first cast or in maintenance, he was sure the advocates of the tube-frame construction would be listened to. During his own experience for the last twenty-six years he had always met with an attentive hearing in reference to any means of reducing the cost of maintenance, as well as of effecting a saving in first cost.

Mr. Henry Sandham wished to express his concurrence with Mr. Sterne's view, as he failed to understand why the same tubeframe construction should not be tried for the present short four-wheeled wagons, so as to meet the wants of English railways, and to try how far the light tube-frames would prove successful for lightening the dead weight and at the same time increasing the carrying capacity of the short wagons now in use.

Mr. HenRy J. MaRten, through whom the paper had been communicated, was satisfied that the present discussion of the subject would be found eventually to bear fruit and to produce good results in connection with the English system of carriage of goods by 
(Mr. Henry J. Marten.)

railway, more especially of those known as the mineral class. Although his own connection was principally with water carriage, and it would not therefore seem to be altogether to his immediate interest to advocate the introduction of anything that would materially lessen the cost of railway carriage in competition with water, yet he was convinced that, if a saving could be effected in the cost of carriage, such saving, in whichever way made, whether by water or by rail, would eventually react favourably upon the other mode of carriage. There could be no doubt that, the cheaper the carriage of goods could be made in England, especially of the heavy raw description he had already alluded to, the longer would this country be able to maintain its commercial position.

Mr. T. Hurry Riches, Member of Council, considered the paper was highly interesting to railway engineers, who were all trying to progress with the times. Reference had already been made to the introduction of pressed-steel underframes (page 501), as a means of diminishing the dead weight of railway wagons; and also to the reduction of tare in the Great Western Railway wagons (page 498). The latter he knew to be a fact; for their former 8-ton narrow-gauge wagons had been reduced to $3 \cdot 80$ and $3 \cdot 25$ tons tare since they had been constructed with iron and steel frames and bodies, instead of with oak or other wood bodies. As far as long bogie-wagons were concerned, notwithstanding their advantages, there were several grave objections to them for English railways. Their advantages appeared to him to be fairly good for carrying rails or clay or heavy traffic of that kind in bulk. But then, coming to the coal traffic, there were few districts in England where it was not wanted to tip the coal wagons for shipment; and he failed to see how such a long wagon as that described in the paper was going to be tipped with anything like reasonable dispatch, and without entailing upon the docks and railways an enormous expenditure in the alteration of their tips and other appliances. The expenditure might indeed be a small item relatively to the prospective economy of the change; but he was sure it was a serious consideration, and it must be faced before any rash experiment was adopted in placing a large number of these long 
wagons upon English railways. With regard to other goods traffic, it had already been mentioned by Mr. Dawson (page 494) that a large percentage of it was carried in light parcels, or at any rate in small parcels. A large proportion of truck loads of goods in England he believed did not exceed $2 \frac{1}{2}$ tons. If indeed it were possible so to collect and classify the goods traffic as to be able to load the long wagons fully, and hence take advantage of their decreased tare, he could quite understand that it would be a great advantage to the English railways; but when goods had to be sent in small lots in different directions and over branch lines, he thought the longer wagons, instead of reducing the dead weight, would materially increase it. Therefore, unless for special traffic, he failed to see where their advantage came in for the railways in this country.

As to the tube-framing of the wagons, he had himself had some experience of tube-frames for some special trucks, and he had always found it a difficult matter to get them to hold rigidly together. In a short period after they had been put together, and even when he had welded them, or put flanges on the ends and bolted them up somewhat in the way shown in the drawings illustrating the paper, they appeared gradually to work loose and become like an old umbrella. There was a good deal too much freedom about them, too much elasticity and play in the parts; and with the heavy and fast traffic in England he was sure the railways could not afford to run the risk of serious accidents through having anything other than a thoroughly rigid frame and body for their wagons. Like Mr. Sterne (page 503), he should have been glad to have some definite information given as to the use of the tube-frames in the ordinary short wagons of standard length. He did not himself see why the tube-frame should not be adapted and adopted for the short wagons, whereby something might be economised in the tare. But some of the statements made in the paper were hardly in accord with English practice. The tare of an 8-ton wagon was given (page 485) as 6 tons, and of a 12-ton wagon (page 488) as 10 tons. Now the tare of a large percentage of English wagons was only $5 \frac{1}{4}$ tons for a 10 -ton load. On the North Eastern Railway there were many instances of 6 tons tare for 10 tons load, but in South Wales the tare rarely exceeded $5 \frac{1}{4}$ tons for that 
(Mr. T. Hurry Riches.)

load. The adrantages gained therefore were not of the magnitude claimed in the paper. There was certainly one point that was worthy the careful consideration and experiment of English engineers, namely the use of the chilled cast-iron wheels. For mineral and other slow traffic he thought these wheels might be beneficially adapted to the present rolling stock, with a reduction of course in the tare, but not a large reduction.

With reference to the bogies, he failed to see why in a bogie truck there should be any less skidding of the inside wheels in going round a curve than in an ordinary four-wheel wagon; for after all the bogie truck was only a shorter four-wheel wagon. At the same time, wherever a long wheel-base was used, there was no doubt an advantage accruing from the flexibility of the bogie. He had himself had a great number of bogies running under engines; and he might mention one experiment which had shown him the advantage of a bogie on a long wheel-base. Some of his engines had six wheels coupled and $14 \mathrm{ft} .8$ ins. wheel-base, and were 32 tons weight. $\mathrm{He}$ took out the trailing wheels, did away with the tender, and put a bogie under the trailing end, giving the engine 1,100 gallons of water to carry: which altogether added something like 12 tons to its weight. By doing away with the tender he saved 16 tons; but up the ordinary gradient of 1 in 200 the same engine succeeded in taking 8 per cent. more load with the same steam-pressure, and with the adhesion of four wheels instead of six. That was an illustration showing the advantage of a flexible wheel-base upon any road. As to bogies under carriages, the present practice was to give more accommodation, larger air-space, and so on, for the passengers; and this was not accomplished without a material increase in the dead weight carried. A carriage for seventy persons now weighed 16 or $16 \frac{1}{2}$ tons, whereas formerly a carriage for fifty persons weighed less than 10 tons. As far as passenger traffic was concerned, the railways were really compelled to increase the dead weight or non-paying load. As to mineral traffic he hoped it would be possible to get some further information about the flexible tube-frames, so as to see whether anything could be saved in the weight of the present wagons. It this could be accomplished, it seemed that the use of a longer wagon 
was not at all applicable to the general traffic of English lines; and if a long wagon was not required, equally a bogie was not required. The matter resolved itself he thought into the question of a short wagon, something similar to the present, and of the smallest possible tare, which might be still further reducedlby using chilled cast-iron wheels.

The President said that letters had been received from four gentlemen who were unable to be present, which it might be well to read at this stage of the discussion.

Sir James Ramsden, Vice-President, wrote that the tube-frame wagons had been running on the Furness Railway for nearly two years. 'They had been in constant use, carrying traffic from the steel works to the docks, their regular load being 30 tons, while the tare of the wagon was only 8.3 tons. The repairs to them had been practically nil ; and they had given him such satisfaction that he had ordered a further number.

Mr. R. H. Twelvetrees, chief goods manager of the Great Northern Railway, wrote that one of the 30-ton tube-frame wagons had been in use on that railway for the past six or eight weeks. It was first put to use between the ironstone pits at Caythorpe near Grantham, and the West Yorkshire Iron and Coal Co.'s furnaces at Ardsley near Leeds. The tare of the wagon itself was $8 \frac{1}{2}$ tons; and on weighing five of its net loads they were found to range from $20 \cdot 6$ to 30 tons ; the tare thus ranged from 29 to 22 per cent. of the gross weight. By way of comparison 278 Great Northern Railway wagons running between the same places had also been weighed, with the following results :--average tare $5 \cdot 2$ tons; average net load $8 \cdot 6$ tons; tare in percentage of gross weight 38 per cent. The report as to the running of the tube-frame wagon was everything that could be desired; and the deflection in the centre ranged from 1 inch to $1_{1}^{\frac{1}{1}}$ inch. One journey had also been made from Poplar, London, to Cambridge, with a net load of $24 \frac{1}{2}$ tons of grain, the tare being then $25 \frac{3}{1}$ per cont. of the gross weight. The wagon had fixed sides 
(Mr. R. H. Twelvetrees.)

15 inches high, and was therefore inconvenient for general traffic; the fixed sides also entailed a good deal of extra expense in loading and nnloading the ironstone, but this he hoped would be obviated when the sides were made higher and doors provided. It was now in the possession of the author of the paper, in order that it might be fitted with sides about $3 \frac{1}{2}$ feet high, with two let-down doors on each side; after it had been received again so altered it conld be tested with traffic of a more general character.

Mr. J. W. Johnstone, locomotive engineer of the Cork and Bandon Railway, wrote that he had endeavoured to get some of the tube-frame wagons on that line, but some of the bridges were not up to their weight. The traffic department were not at all in favour of these wagons, chiefly on account of the difficulty in handling them, and because of not being able to get sufficient load for most stations for one wagon.

Mr. J. F. Mostyn Clanke, of the Mannesmann Tube Works, Landore, wrote that in these days of mild steel it seemed surprising wrought-iron had been chosen as the material for construction, especially in those portions where tubes were used. In the case of welded tubes no doubt wrought-iron was more reliable than steel; but with the numerous processes by which weldless steel tubes of small size were now made, it seemed to him that greater advantages might accrue from the use of steel tubes, considering the reduction of section that would be possible. The first cost would perhaps be greater; but this would be well balanced by greater carrying power and durability, with the same or slightly smaller sectional area. For an example might be taken the comparison between a wrought-iron welded tube and a steel weldless tube, which had been given in a paper lately read before the Society of Arts (Journal 23 May 1890, pages 651-2) by Mr. J. G. Gordon upon the Mannesmann process of rolling weldless steel tubes. There a marked difference was manifest between the strength and behaviour of the two. A steel tube about $3 \frac{1}{4}$ inches outside diameter and about 1-8th of an inch thick bore a longitudinal compression load of 35 tons 
per square inch of metal, without a fracture of any kind appearing in the tube wall, which was much bent up; while a wrought-iron tube of the same thickness but $3 \frac{3}{4}$ inches outside diameter stood a compression of only 21 tons per square inch, under which the fibres of the iron opened in the bends at intervals, parallel to the axis of the tube.

It was interesting to know that the tubes used in the wagons now described had given such satisfactory results in practice in the positions assigned to them; and as far as railway rolling stock was concerned, the tube-frame construction appeared to him to be decidedly a step in the right direction; for it was clear, as pointed out in the paper, that the present European mode of construetion might be improved. There seemed also to be some tendency among engineers to use tubes more freely in general construction; and having himself recently been considering a truss in which tubes might be used for both compression and tension members on a large scale, he should like to ask the author for any information he could give as to the use of steel tubes, instead of the wrought-iron tubes described in the paper.

Mr. J. L. WIrkrnson, chief goods manager of the Great Western Railway, said the first thing that struck him in connection with the paper was the seeming assumption therein that the bogie truck was new to England. That was not quite the case. There were traces of the bogie principle in work on the Great Western Railway nearly fifty years ago; and the idea he believed had been transported from England to America.

The traffic moved on the railways in England was different in character from that in the United States, where the distances were greater and the loads heavier. Practically it might be said that in England there was more of a retail than of a wholesale business. General merchandise was usually carried in small lots, and started on one of the main lines, off which ran branch lines, and off those branch lines again there were other branch lines: so that it was difficult to make up big loads for bogie wagons. The tonnage on the railways of the United States exceeded he believed the total tonnage 
(Mr. J. L. Wilkinson.)

on the European continent, and was moved in large consignments upon fairly level lines; and it was patent to everybody that in this country there were not only the small lots, the short hauls, and the cross-country train services, but there was also a great deal of up and down hill work, and comparatively little level road, which were important factors in considering the question. Then the style of doing business was different. English traders, whether in London, Manchester, or elsewhere, always expected that any goods consigned to a railway in the afternoon should reach their destination the next morning; and the railways laid themselves out to fulfil this expectation. That was not the case in North America.

As to the difficulty of getting a full load, it had been stated only recently by Mr. Findlay, of the London and North Western Railway, that the average load per wagon which they were able to get of general merchandise on that railway was under two tons. Recently too he had himself taken the opportunity of testing the loading on the Great Western Railway; and he had found that they were not able to get more than an average of $2 \frac{1}{2}$ tons for the week during which the test was made. It followed that in ordinary circumstances the usual 10-ton wagon was more than sufficient for the traffic. Having had to manage formerly a railway in South America, he had had some experience there in the working of long bogie wagons; and subsequently in this country he had tested the experience gained upon the other side of the Atlantic, having arranged with $\mathrm{Mr}$. Dean for a general goods wagon to be built of the standard North American type, and to be put to work in the most favourable conditions possible on the Great Western Railway. The results of that experiment were closely pertinent to the present enquiry. After a great deal of trouble, and trying the wagon in different parts of the country on the Great Western system of nearly 2,500 miles, he had found it was impossible to get anything like a full load of general merchandise, except between two pairs of stations, namely between London and Birmingham, and between London and Bristol. Nowhere else was it possible to get a full load in both directions. On totalling up the results of 204 journeys made by that wagon during the past twelve months, he had found that the average load carried between those 
particular pairs of stations was only $7 \cdot 35$ tons. The maximum load that he was able to get was $12 \cdot 35$ tons. Hence on many occasions all the traffic could have been easily carried in a 10-ton wagon of the English type; and in the few cases where it could not be so carried, it could have been taken in two such wagons. As a matter of capital cost it was seen from the information given in the paper (page 489) that two wagons of the English type could be provided at a less cost than one of the North American. In that direction therefore no advantage was offered, so far as he had been able to ascertain. It was well known that many bogie wagons had long been in use on the English railways. The wagons used for carrying boilers, masts, and other heavy loads of great length, had been of the bogie type; and if more traffic could be got, such as would justify the use of bogie wagons, the railways would be glad to use them more.

Another point was that there were obligations laid upon railways in England, which were not thrown upon those in the United States. The English railways had to comply with certain government obligations, under which it was the practice to give a greater strength to the wagons than was given to the American, so far as could be gleaned from the information already furnished. It was well known that the standard English wagon, which was marked as carrying 10 tons with a tare of about 4.85 tons, had really as much as half the carrying capacity of the long American wagon, although the latter was said to be capable of carrying 30 tons. It would therefore bo seen that the English wagon might, under the same conditions, bo fairly marked to carry more than its present load of 10 tons, if the same elements were to reign in its construction.

It had already been pointed out how an increase in the length of wagon would necessitate changes in turntables and hydraulic hoists, such as existed especially in London and other large towns; and also in coal-tips, coal-drops, weighing machines, and cranes. With regard to turntables, a suggestion to be inferred from the paper (page 488) was that they might possibly be dispensed with, and be replaced by triangles; but that was scarcely a practical suggestion, because, although the use of a triangle would enable an engine or a wagon to be turned the other way ruund, it did not put the wagon in the 
(Mr. J. L. Wilkinson.)

place where it was wanted, which a turntable enabled to be done. In addition to this, there was a difficulty in large towns in spariug land enough for laying out triangles (page 502); having constructed some himself, he was able to appreciate this aspect of the question. Another difficulty would be in moving the long wagons about by horses in station yards. A bogie wagon with a tare of 10 tons and carrying 25 or 30 tons load would be more than could easily be handled, especially if the gradient was a little against it. There was also a difficulty which had not been mentioned in connection with the use of the long heavy wagons intermingled with the existing shorter wagons, namely that, according to the present construction of the long wagons, there was a danger of the buffers getting locked with those of the short wagons; but he was aware that this was a difficulty which could be easily obviated. When one of these bogie wagons got off the road, he knew from painful experience that it was uncommonly hard to get it on again ; it was so difficult to handle it when it got off the line, especially on a soft road. Moreover as there were some fifty millions of money invested or spent in England in the manufacture of the English wagons, it would be a rather serious thing to change their construction, apart altogether from changing the tips and other appliances. And in regard to heavy traffic in bulk, like coal and iron ore, the latter was often sent, both in North America and in England, in smaller wagons specially constructed for the purpose, from which the bottoms could be removed, or traps opened, to allow the ore to descend from a higher to a lower level. In that respect he presumed there would be a little difficulty with the long bogie wagons; and even if the opening were made in the bottom of the wagon, shovelling would also be necessary, or some means of getting the contents to the opening. Beyond the fact already stated that bogie wagons were not altogether unknown in England, it could further be said that there was not a wagon works of any importance in this country which did not constantly make bogie wagons to send to the colonies and elsewhere. The method of making them was well understood; and he hoped that whatever form was the best would be adopted in England. 
Mr. William Dean said that, although he had never yet had the pleasure of visiting America, he had seen one of these tube-frame bogie wagons when first exhibited in London in August 1888, and had ever since taken a great deal of interest in them ; and he certainly regarded their construction as clever and ingenious. At the same time they were built in such a way as to be adapted more especially for American than for English traffic. It would be observed that the buffers were placed much nearer the centre of the wagon, so as to come in line with the two inside longitudinals. This rendered it unnecessary, he presumed, to provide any diagonal bracing, which he thought would be essential in the case of wagons fitted with buffers placed according to the English standard, $5 \mathrm{ft}$. $8 \frac{1}{2}$ ins. apart from centre to centre; and especially would such diagonal bracing be necessary in the case of wagons used on lines with severe curves.

But after all, the business of carrying heavy loads was still somewhat in its infancy, even in America; and he might therefore refer to a few expressions of opinion which he had met with in American publications relating to this subject. According to the Report of the sixteenth annual convention of the Master Car Builders' Association in June 1882, during the discussion upon the report of the committee on the carrying capacity of freight cars, Mr. C. A. Smith said (page 58), in answer to an enquiry about putting 30 tons into the cars, "Into how many cars can you put 30 tons of freight? that is, of certain classes of freight? You can just as well put that freight into large cars as you can into small ones. Of course we understand with the 30-ton car that it is only when that class of freight which we now put into the ordinary cars is used that it will have that capacity; and I will say again, how many cars have been built in former times to carry 10 tons, to which all that has been done to make them carry from 15 to 20 tons has been to alter the figure on each side, and they would carry the increased load safely? Your cars that were 10 tons capacity are now carrying 20 tons, and carrying it safely; and all it took was a painter to change the capacity from 20,000 lbs. to 40,000 lbs." That quotation might to some extent account for part of the progress which had been heard of as taking place in the reduction of freight expenses in America. In the 
(Mr. William Dean.)

report of a subsequent meeting of the same association in 1889 he had also found the same subject touchedjupon by Mr. Rogers, railroad commissioner of the State of New York, who said (page 7), "It seems to me-I am an engineer myself-that the limit is getting pretty rapidly reached with the loads you propose to put on your cars. When you get $60,000 \mathrm{lbs}$. on your car, the effect that it has upon the rails and upon the road-bed, and upon the ties, and above all upon the bridges, is a pretty serious thing, particularly at the high rates of speed at which these heavy loads are now being transported; and it seems to me that the time has come when you should consider whother the limit of these very heavy loads has not been pretty nearly reached. If you go on making them any heavier, it seems to me you will have entirely to reorganize your road, and build it on a different basis." It should be observed that 60,000 lbs. was equivalent to not quite 27 English tons: so that a 30 -ton car in America meant really a 27-ton car in England.

That the subject was still comparatively young in America was proved by the fact that only so lately as September 1889-little more than a year ago--had the Master Car Builders' A.ssociation (Report June 1889, pages 87-109 and 211, and plate viii) settled a standard axle for cars of 60,000 lbs. capacity. This showed that the experience of running such heavy loads had not as yet been fully developed.

Then with regard to chilled-tire cast-iron wheels, there could be no doubt that a considerable fraction of the saving in tare must be put down to the credit of those wheels. Taking the standard axie just mentioned, and fitting it with a pair of 33-inch chilled wheels, as compared with the axle and the 36-inch wheels with steel tires that were generally in use in this conntry, there would be a saving of probably about $2 \frac{1}{2} \mathrm{cwts}$. on the pair of wheels and axle, making a saving of $10 \mathrm{cwts}$. altogether in the two bogie trucks of the long wagon, which of course was a consideration not without its attraction. But chilled wheels, as far as he knew, had never found favour in this country. On this subject he found in the report of a meeting of the American Railway Master Mechanics' Association in June 1888, in the discussion upon the report of a committce on cast-iron wheels, 
that Mr. J. N. Lauder stated (page 155), as one of the committee who had agreed to the report:- "There are some railroads that will not trade with a firm or a concern that is known to dabble in poor wheels. They only trade with those well-known firms whom years of experience have proved [to] make a good wheel, and whose business standing will be a guarantee that they will not make a poor wheel. But I am sorry to say that the number of roads which take that view are largely in the minority, and the consequence is that the chilled car-wheel is deteriorating to [such] an extent that the roads at the present time are obliged to use other wheels, solely on ascount of the danger attending the use of chilled wheels. . . . . Something has got to be done to stop the use, and the manufacture if possible, of these poor chilled wheels." In September 1889 the Master Car Builders' Association (Report June 1889) had adopted a specification (page 203), in which the maker of the wheel was required to give a guarantee that in certain cases he would incur a charge for a defective wheel. An exception in his favour was made in the case of wheels removed for causes enumerated (page 205), of which the two following struck him as important:- "Chipped flange; broken flange, if the breakage is not caused by seams, worn through chill or worn flange." The liability to such defects as these had always seemed to him to be a somewhat serious risk in connection with the use of chilled wheels; and as the engineers in America were speaking of their increasing speeds and increasing loads, the question suggested itself whether the troubles they were experiencing were not rather due to these causes than to a deterioration in the manufacture of the wheels themselves. He also observed a statement in the " Engineering News and American Railway Journal" of 14 th June in the present year (page 553) that " On June 6th the north western passenger train from Freoport to Chicago was derailed by a broken wheel near Rockford, Illinois. The train ran about 200 feet and then toppled over, wrecking the entire train, and killing the engineer and four trainmen, and injuring two section men and several passengers." Of course that might be an exceptional occurrence; but not having full access to all the statisties of American practice, these items which had come under his notice were such as to cause him to think 
(Mr. William Dean.)

seriously before he could accept the responsibility of putting the chilled wheels to work upon an English railway. (See page 527.)

Mr. John C. Cathodn, Vice-President of the Central Railroad and Banking Company of Georgia, said the question of transport had lately come before the executive committee, of which he was one, having the management of about 9,000 miles of railway in the southem portion of the United States, comprising the East Tennessee Virginia and Georgia and the Richmond Danville and West Point Railways, together with the old lines of the Central Railroad and Banking Company of Georgia. The executive committee had appointed three eminent engineers to give them the advantages of all modern facilities for transport. Since the war of twenty-five years ago the American cotton crop had increased from three million bales a year to seven million bales, which had greatly increased the tonnage over those railways. Moreover, whereas ten years ago the production of pig iron was scarcely known in the southern states, the tonnage now produced was eight times as great as that of the entire cotton crop, which had previously been the principal industry of the country. It had therefore become a matter of great importance to avail themselves of the cheapest method of transport.

The Central Railroad and Banking Company of Georgia was one of the oldest of the American railway companies. The first railroad in America was the South Carolina, which ran between Augusta (Georgia) and Charleston. The next was that of the Central Railroad and Banking Company, Georgia, which however was entirely destroyed after the war, during the march of General Sherman through Georgia. The iron rails were heated and lapped round trees, and nothing but the bare road was left. The track was relaid as speedily as possible with the old iron rails, which were beaten out straight. At that time the heaviest locomotive weighed only 20 tons. It had since been found necessary, on account of the heavier traffic, to replace the original rails weighing 56 lbs. per yard with 60-1b. and afterwards with 70-1b. rails, which latter were now the lightest that were laid on those railways. The engines had also been increased from 25 tons up to the six-wheeled engines of the Baldwin 
make, weighing 90,000 lbs. These had involved improving the road bed throughout, and strengthening the bridges : all of which had cost a great deal of expense. With a view to the easiest method of transporting their heavy traffic, they had sought out the lightest cars having the greatest strength, so that one engine should be able to haul the largest amount of tonnage. The car they had adopted as the lightest and the most available was the tube-frame bogie car described in the paper. There were now four hundred of these cars on their lines, and they had decided to adhere to this construction for the future. The tonnage having so greatly increased, it was necessary with such long distances of haulage to make one engine haul as much as possible; for if on the long single-track lines in America one train had to be sent out behind another, it would seriously interfere with the traffic. With the Baldwin locomotive and the tube-frame car the engineers reported that it was found a greater tonnage could be hauled by one engine than on any other plan that had been tried.

Mr. W. A. Adams observed that, if the present standard English wagon to carry 10 tons could not get average loads of more than $2 \frac{1}{2}$ tons ordinarily up to $7 \frac{1}{2}$ tons on exceptional routes, as mentioned by Mr. Wilkinson (page 510), it seemed natural to ask what need there was that it should be built to carry a maximum of 10 tons with a tare so high as $4 \cdot 85$ tons and upwards.

Mr. JEFFEnDs considered there was room for a saving of 67 per cent. to be effected in the working expenses of the railways in this country; and only 9 per cent. of that saving was to be attributed to the saving in tare by the use of the tube-frame car itself, the balance being made up by the difference between the rigid wheel-base of the standard short wagons and the flexible wheelbase of the bogie wagons. The four-wheeled wagon with its wheels attached rigidly to the frame exerted a lateral pressure upon the rails; the flanges of the wheels were forced against the rails not merely by the momentum of the wagon itself but also by that of the load as well, whereby the violence of the 
(Mr. Jefferds.)

shocks was greatly increased. With the bogie trucks 90 per cent. of the vibration was taken up without being imparted to the body of the car and its load. This saving of shocks he was satisfied would cover the greater part of the expenses incurred in maintenance of permanent way and in repairs and renewals of wagons.

On the 9,000 miles of railway in Georgia, mentioned by $\mathrm{Mr}$. Calhoun (page 516), running through a country which only twentyfive years ago was derastated by war, there were now fewer miles distance between the stations than on the Great Western Railway; and there was not a four-wheeled wagon on the entire system. There were many towns to which they delivered less than six tons of goods in the whole year; yet the traffic was all conducted in the long bogiewagons. On a canal serving a number of towas no one would think of allotting to every customer who wanted to send $2 \frac{1}{2}$ tons of goods a separate boat all to himself. The principle applying to the long bogie-wagons was the same that had led up to ocean-going ships which would carry 10,000 tons. That was the way to reduce the rates; and only today he had received an offer of freights from New York to Liverpool at 15s. a ton, instead of $£ 1$ as for months past.

As to the suggestion of adapting the tube-frame construction to the existing short wagons (page 503), he regarded the principle of the short four-wheeled wagon as wrong in every way. What could be done with a four-wheeled street van, if built on the same principle as the wagons on English railways? If it wanted to turn a corner, it would have to be lifted round; and that was what had to be done with the wagons on railways, and it was that which required so much power. Every wagon in a train going round a curve was trying to run at a tangent, and therefore required extra power to haul it round the curve. However extraordinary it might seem (page 493), the power required to haul 32 of the short four-wheeled wagons loaded with 8 tons each was really sufficient to move as easily 40 of the long bogie wagons loaded with 30 tons each, with much less wear and tear to the permanent way and to the vehicle.

With regard to the unloading of coal from the long wagous, a photograph was shown in Plate 144 of one of the long wagons built for loads of 30 tons and in some cases 40 tons of coal, which was 
discharged within $1 \frac{1}{2}$ minutes through the hopper bottom of the wagon. The average load of $2 \frac{1}{2}$ tons of general merchandise per wagon, mentioned by Mr. Wilkinson (page 510) as obtained on the Great Western Railway, had reference to only 25 per cent. of the traffic of that line, 75 per cent. being minerals which were carried in fully loaded wagons.

With reference to steel tubes (page 508), of which a trial had been made for the tube-frames of the long wagons, it had been found that, on straightening them after they had been subjected to a bend of short radius, a crystallization had taken place in the steel tubes, which weakened them seriously. The result was that the use of steel tubes had been abandoned for the present; and he did not think that by their use anything could be gained in reduction of weight. Perhaps the time might come when steel tubes might be used; but as long as iron tubes could be got at the cost at which they were now obtained, they would be preferred to steel tubes.

For the last two or three years he had been trying to procure in England the tubes and malleable castings and other parts, required for the cars which he had been sending to all parts of the world. The malleable castings supplied from America and used in this country had been tested for years, and never found wanting. They were delivered in London at $178.4 d$. per cwt., whereas the lowest quotation he had received in this country was $24 s$. No steel castings that he had seen would answer, on account of their being weakened by blow-holes. The tubes were got from Conshohocken, Pennsylvania, 33 feet 2 inches long, plugged and screwed at each end, $2 \frac{1}{2}$ inches. inside diameter and $2 \frac{7}{8}$ inches outside; and were delivered in London at $288.6 d$. each, as against $32 s$. asked in Birmingham exclusive of the carriage to London. The grey-iron castings cost 7-8ths of a penny per $1 b$.; but the lowest price in this country was $1 \frac{1}{2} d$. or $1 \frac{3}{4} d$.

The bogie with pressed-steel frame, made by Mr. Samson Fox (page 501), was certainly a great improvement on the old squareframed truck previously used in the United States; but the squareframed bogie had been abandoned in the United States on account of its rigidity, and had been marked in the carbuilders' dictionary of 1884 as no longer in use. As to the pressed-steel frame being lighter, 
(Mr. Jefferds.)

he did not know the weight of the bogie so constructed; but from the experience he had had with it he considered that, the parts being riveted together, it could not carry with safety so heavy a load as the bogie described in the paper, in which there were no rivets at all. The weight of the latter, complete with wheels and axles, was just under 2 tons, and the cost was about $£ 20$, the cost of the two trucks for the long wagon being about $£ 40$. The cost of the ordinary gondola car described in the paper was $£ 150$. The tube-frame of the car was what had cost so much time and trial to mature into the present success; the great difficulty had been to hold the tubes fast. The fastenings now used, as shown in the drawings, were made to hold the tubes as tight as if in a vice. The so-called 30 -ton cars were really made to carry 32 gross tons ; 32 tons was the regular limit of load for a speed of 40 miles an hour. The long car thus took the place of four of the old short wagons costing say $£ 240$ altogether, whereby a saving in cost was effected of from 30 to 40 per cent.

With the long wagons it had been objected (page 512) that no horses could be used for shunting in station yards. In America horses were not used in station yards, because it was not necessary, owing to the adoption of other devices whereby a boy could move one or more of the long cars loaded with 30 tons each.

Diagonal bracing, alluded to by Mr. Dean (page 513), had never been found necessary in the framing of these wagons, on account of the way in which the tubes were fastened together, the fastenings holding them as tightly as if in a vice. Not only had it never been found necessary to use any diagonal bracing in the tube-frames, but it was desirable to avoid its use, because it stiffened the wagon too much. One of the tube-frame wagons he should be happy to place at the disposal of any locomotive superintendent in this country, in order that he might load it with 30 tons and put it upon a curve, and back into it at the rate of ten or even twenty miles an hour with a train of loaded ordinary wagons; he was ssatisfied it would be found that it could not be so disabled thereby"as to prevent its running a hundred miles with its load after the test.

With regard to the chilled wheels (page 514), there were now more than eight millions of them in use in the United States, and 
perhaps not more than 100,000 of the steel-tire wrought-iron wheels such as were used on the railways in this country.

In regard to carrying traffic over long distances (page 498), it would be found on referring to the statistics of railways in the United States (issued by the Inter-State Commerce Commission for the year ending 30 June 1889, page 29) that the average distance over which one ton of freight was hauled on all the railways throughout the United States was only $127 \cdot 36$ miles. On the Pennsylvania Railway it was 135 miles, and the average charge was $42 \frac{1}{2}$ pence per ton. On the London and North Western Railway the average charge on all classes of freight was 42 pence per ton. Assuming the freight charge to be only one penny per ton per mile, the average distance through which a ton of freight would have been moved on the latter railway would be 42 miles. It seemed clear therefore that on the Pennsylvania Railway with the bogie-truck system the charge for moving freight 135 miles was practically the same as on the London and North Western Railway for only 42 miles.

From his own experience both in the United States and in England he failed to see wherein the traffe was different, except that in the former there was more retail business than wholesale. The conditions in the United States were somewhat different, namely:first come, first served; immediate despatch of all freight received; immediate notice to consignee of arrival at destination; consignee must take goods within twenty-four hours from notification of arrival ; no terminal charges whatever. All goods were received and delivered, loaded and unloaded, by the railway servants at the station platforms. If a car containing only $2 \frac{1}{2}$ tons were wanted by a trader to be left in a siding at its destination, he must pay the price for a car fully loaded with the same class of freight; and if it were not unloaded within twenty-four hours, a mileage rate was charged, equal to what the car could earn if running. The policy of the receiving department was to load all cars as full as possible, and of the delivery department to empty all loaded cars with the utmost despatch. Thus if any trader were extravagant enough to require a special car for a mere handful of goods, it had to be paid for by himself, and not as in England by the public generally. 
(Mr, Jefferds.)

From page 50 of the railway returns of 1889 to the Board of Trade it would be found that the total tonnage of the Great Western Railway for 1888 was 25,944,703 tons, of which $19,653,714$ tons were minerals and $6,290,989$ tons were general merchandise; that is, $75 \frac{3}{4}$ per cent. were minerals which were carried in full loads, and only $24 \frac{1}{4}$ per cent. was general merchandise, of which the average load per wagon had been stated by Mr. Wilkinson (page 510) to be only $2 \frac{1}{2}$ tons. This general merchandise was what was termed in America retail or detail traffic. From page 51 of the same returns it would be seen that the receipts for minerals were $£ 2,095,321$, or $1 s$. $7 \frac{1}{2} d$. per ton; while those for general merchandise, including cattle, were $£ 2,377,490$, or $8 s .10 \frac{1}{2} d$. per ton. Assuming that the mileages of merchandise and of minerals were equal, the charge per ton for merchandise was $5 \frac{1}{2}$ times greater than for minerals; and this was just what was complained of by the traders, manufacturers, and farmers. The system of allotting a separate wagon to every one who had a ton or two of goods to send, and permitting him to use that wagon as a storehouse for an indefinite period, was most expensive; and when this was permitted, it should be paid for by the person so using the wagon, whereby the loss would be kept out of the general account. The average rate charged by the Great Western Railway for all classes of freight was at least 1.25d. per ton per mile.

From the report of the New York Central Railway for 1889 it appeared that their freight traffic was 70.35 per cent. general merchandise, and only $29 \cdot 65$ per cent. minerals, including pig and bar iron, and iron and steel rails. Hence the percentage of retail and detail traffic on that line was $2 \cdot 9$ times greater than that of the Great Western Railway. The main line of the New York Central Railway was only 441 miles long, and the average distance that one ton of freight was carried was 184 miles. The whole of this traffic was conducted in long bogie-truck cars at an average charge of $0.38 d$. per ton per mile. At the same time the wages paid were double of those on the Great Western Railway.

The following comparison of the working expenses on these two railways, without reference to the difference in wages, was calculated for the Great Western Railway from the railway returns for 1889 to 
the Board of Trade (page 50), and for the New York Central Railway from their own report for the same year :-

$\begin{array}{ccc}\text { Working Expenses } & \text { Great } & \text { New York } \\ \text { per ton per mile. } & \text { Western. } & \text { Central. } \\ & \text { Penny. } & \text { Penny. }\end{array}$

Maintenance of way, works, \&c. . . . . $0.1294 \quad 0.0411$

Locomotive power (including stationary engincs) . $0.1611 \quad 0.0696$

Repairs and renewals of carriages and wagons . . $0.0546 \quad 0.0264$.

Traffic expenses, coaching and merchandise . . $0.1766 \quad 0.0779$

General charges . . . . . . . 0.023500 .0041

Rates and taxes . . . . . . . 0.03330 .0138

Government duty . . . . . . . . . $0.0098 \quad 0.0001$

Compensation for personal injury . . . . . $0.0004 \quad 0.0019$

Compensation for damages and loss of goods . . $0.0037 \quad 0.0010$

Legal and parliamentary expenses . . . . 0.00410 .0010

Steamboat, harbour, and canal expenses . . . . $0.0221 \quad 0.0126$

Miscellaneous . . . . . . . . . $0.0001 \quad 0.0079$

Average Working Expenses per ton per mile . $\quad 0.6187 d$. 0.2574 .

Average Charge per ton per mile for moving freight $\quad 1 \cdot 25 t_{\text {. }} \quad 0 \cdot 38 d$.

Percentage of Working Expenses on Gross Receipts $\quad 49.50$ p.c. $\quad 66.42$ p.c.

It thus appeared that on the Great Western Railway using fourwheeled wagons the cost of working the traffic was not only 140 per cent. more than on the New York Central using nothing but long bogie-truck cars, but it was also actually 63 per cent. more than the charge made by the latter railway to their customers. Taking the first five items of the above working expenses as being those that would be affected by rolling stock, if the Great Western Railway had worked their traffic as cheaply as that of the New York Central Railway, their working expenses in 1888 would have been only $£ 1,983,968$, instead of the $£ 4,193,109$ that they actually amounted to; there would thus have been a saving of $£ 2,209,141$ in one year, which would have been sufficient to equip the entire line afresh with modern rolling stock, and to change the terminal appliances to correspond.

It was impossible in America, as it was in England, to load every wagon fully. From the report of the New York Central Railway it appeared that in 1889 the average number of wagons in each train was 37, while the average load carried per train-mile was 226 tons; 
Ост. 1890.

(Mr. Jefferds.)

therefore the average paying load of each wagon was only six tons. Hence it followed that only a small portion of the saving to be effected by the long tube-frame bogie-wagons could be attributed to the difference in the proportion of dead weight. It was the system that must be changed, in order to reap all the benefits of modern railway working. All American railways were equipped with Iong bogiewagons. The average equipment and number of persons employed per hundred miles of road, as reported by the Inter-State Commerce Commission, were as follows, with English comparisons for some of the items:-

Per hundred miles of line.

Locomotives

Wagons in freight service . . . . . . . .

Carriages in passenger service $. \quad . \quad . \quad . \quad$.

Ton-miles per freight locomotive . . . . 4,538,786

Passenger-miles per passenger locomotive . . . 1,430,105

$459 \quad 1,748$

The President asked the Members to join him in passing a cordial vote of thanks to Mr. Jefferds for his paper; it had elicited from many points of view such an ample discussion as he hoped would eventually bear fruit.

Mr. C. P. SANDBERg wrote that, in concluding his paper on steel rails at the recent Sheffield Meeting of this Institution, he had expressed the wish (page 320) that the engineers of the two different departments, the rolling stock and the permanent way, might persevere in working together for the common good. In the present paper, dealing with an important portion of the rolling stock, the bogie system comes prominently under consideration, as compared with a rigid wheel-base. No one can deny the advantages it confers upon the permanent way: firstly, by allowing of sharper curves, and consequent cheaper construction of road; secondly, by better distribution of the load per axle; and thirdly, by diminishing the lateral pressure on curves, thereby giving greater safety and at the 
same time greater economy, owing to the sleepers lasting longer. In his own paper the writer quoted an opinion (page 318) that with a load of 15 tons per axle the lateral pressure on the outer rail of a curve may reach half this amount; and also a calculation that, with the flange rail used on the Northern Railway of France, the Goliath flange rail on the Belgian State Railways, and the bull-head rail on the London and North Western Railway, the pressure of the outer rail on the sleeper is respectively 6.3 and 1.0 and 0.3 ton per square inch, the rolling stock in all three cases having a rigid wheelbase. With the bogie system he is satisfied there would be a great reduction in these pressures for the same weight of rolling stock. In consequence of the general weakness of the road where flange rails are used, base-plates interposed between the rails and the sleepers have been strongly advocated: all the more because in Europe the height of the flange rail is generally greater than the width of its base, thereby increasing its liability to cant and so cause widening of gauge, with consequent risk of derailment. The reason why the American heavier rolling stock can pass over their lighter roads is no donbt that the bogie is there generally in use; and it is matter of regret that its adoption in Europe should have gone on so slowly. Whether it would be most convenient to adopt baseplates for the road or bogies for the rolling stock is a question for the permanent way and rolling stock departments to settle between them : one or other of the two is in many instances urgently required. In England the road is made so strong, as shown by the foregoing figures, that there is no paramount necessity for bogies, while it cannot be denied that under any circumstances they would save the road; and their application to high-speed passenger traffic is already attended not only with great saving to the road, but also with much more comfort in travelling. The introduction of the bogie system in Sweden some years ago on the West Coast Railway, south of Gottenborg, where the road is comparatively light, has not only led to its adoption on the Swedish State Railways, but also lately the engineers of the Finland State Railways having formerly a rigid wheel-base have decided to build nothing but bogie carriages for their lines, after having inspected those on the Swedish railways. The 
(Mr. C. P. Sandberg.)

large long bogie-wagons are particularly advantageous for long journeys and heavy traffic, such as timber \&c.; and for new lines, where no change of system would be involved, their advantages are ominent; but it remains for every railway, on which a different system suited for its special circumstances is already in existence, to consider how far the great expense and trouble of changing would loave any advantage.

As to the special construction of the tube-frame wagons, even admitting that it is the most advantageous for American conditions, it does not follow that it would be so for Europe; it is at least an open question whether the tube frame is really superior to the ordinary frames. The greater number of parts seems rather against it, because ultimately the wear and tear must tell, and justify the old advice not to make in two or three parts what can be made in one. The dead weight would be lessened by using steel, instead of wrought-iron and cast-iron; and although the latter materials may render the construction cheaper in America, where steel is so much dearer, yet considering that in England the extra cost of steel is already so small, and is becoming less almost daily, it seems going a step backwards to use only wrought-iron and cast-iron in the construction of railway wagons. Steel has gradually taken their place with advantage in many parts of locomotives; and whatever crystallization may be going on in steel is going on faster in wrought-iron. Cast-iron wheels may suit American circumstances, but some fifteen years ago the writer strongly objected to their introa uction upon European railways; they were introduced by American engineers constructing railways in Russia for Ia Grande Société, and the latter had afterwards to pay dearly to get rid of them. The present paper he hopes may lead to a more rapid introduction of the bogie system on the continent of Europe, where the railways need it more than in England, as the time and expense required for re-constructing or strengthening the road are so much greater than for adopting bogies. Having recently had an opportunity of inspecting some of the continental railways, he thinks the best long run, as regards both road and rolling stock, is between Paris and Maraeilles, on the Paris Lyons and Mediterranean Railway; 
the bogie carriage 75 feet long, shown at the Paris Exhibition, runs much smoother than the carriages with fixed wheel-base, and requires less tractive power. Were it not that for the sake of economy the existing old rolling stock has to be used up, the adoption of the bogie system for the continental railways would be the greatest improvement ever introduced; and it is only just to say that the development of this system to its present state of perfection is due to America.

Mr. Wildiam Dean supplemented his remarks (pages 513-516) by the following information:-

In regard to the statement in page 482 of the paper, assigning about 90,000 miles as the total for the steel-tire wrought-iron wheel, it has been found on the Great Western Railway that steel tires 2 inches thick on the tread will last from fifteen to twenty years, giving a mileage of from 240,000 to 300,000 miles. The forged wrought-iron wheel centres, after the tires are worn out, are still in perfectly good condition, and simply require re-tiring. Also in a discussion at the New England Railroad Club in Boston on 9th October 1890 (The Railway Engineer, January 1891, page 16), the duration of a pair of steel-tired wheels under a passenger car on the Fitchburg Railroad was given at 399,000 miles by Mr. J. W. Marden, who believed that the cost of running was very slightly in favour of the steel-tired wheel as against the chilled cast-iron wheel. 
Low-sided Gondola Wagon with Drop Ends.
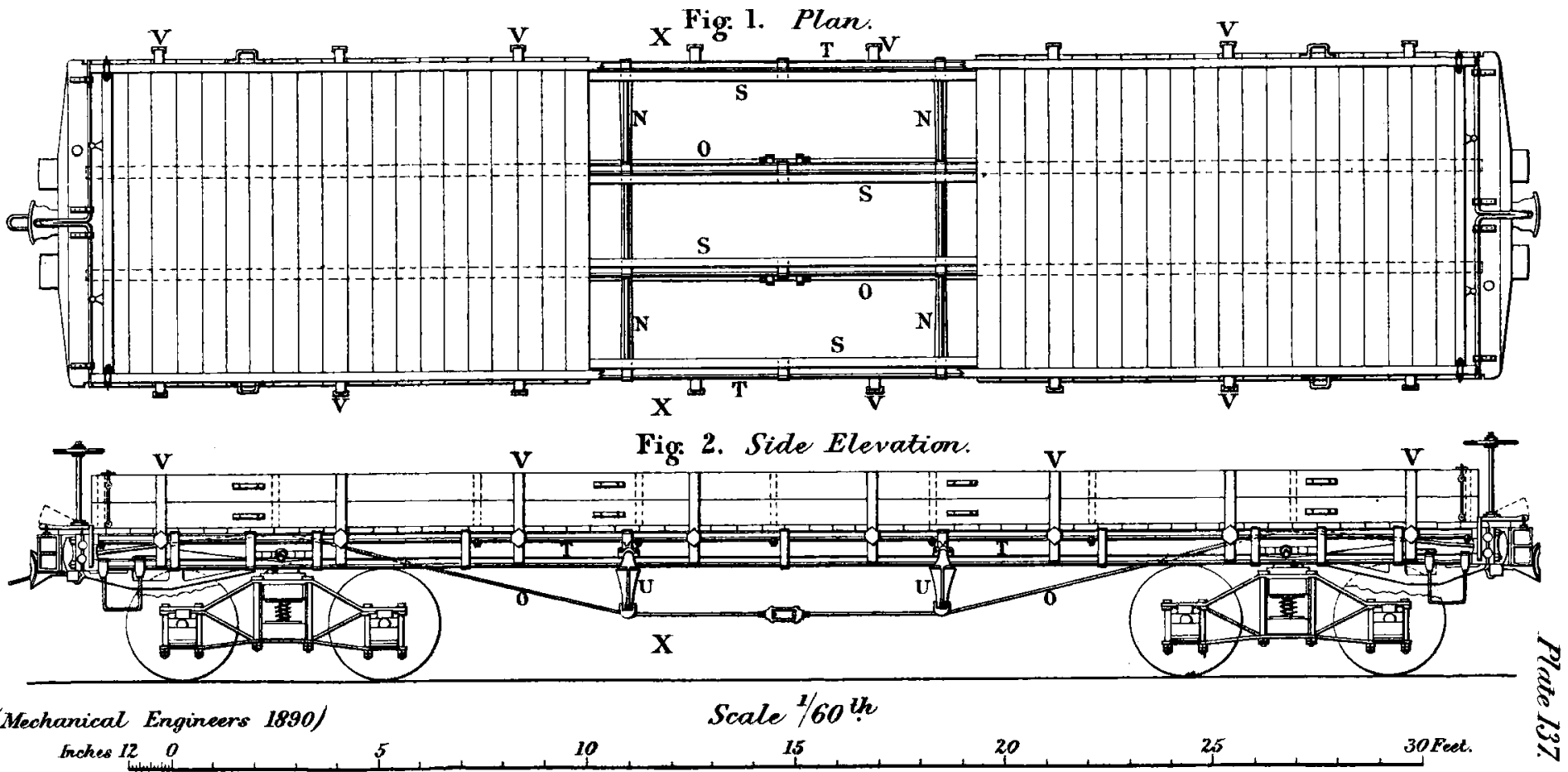
TUBE-FRAME RAILWAY WAGONS. Plate 138.

Fig: 3. Plan of Frame End.

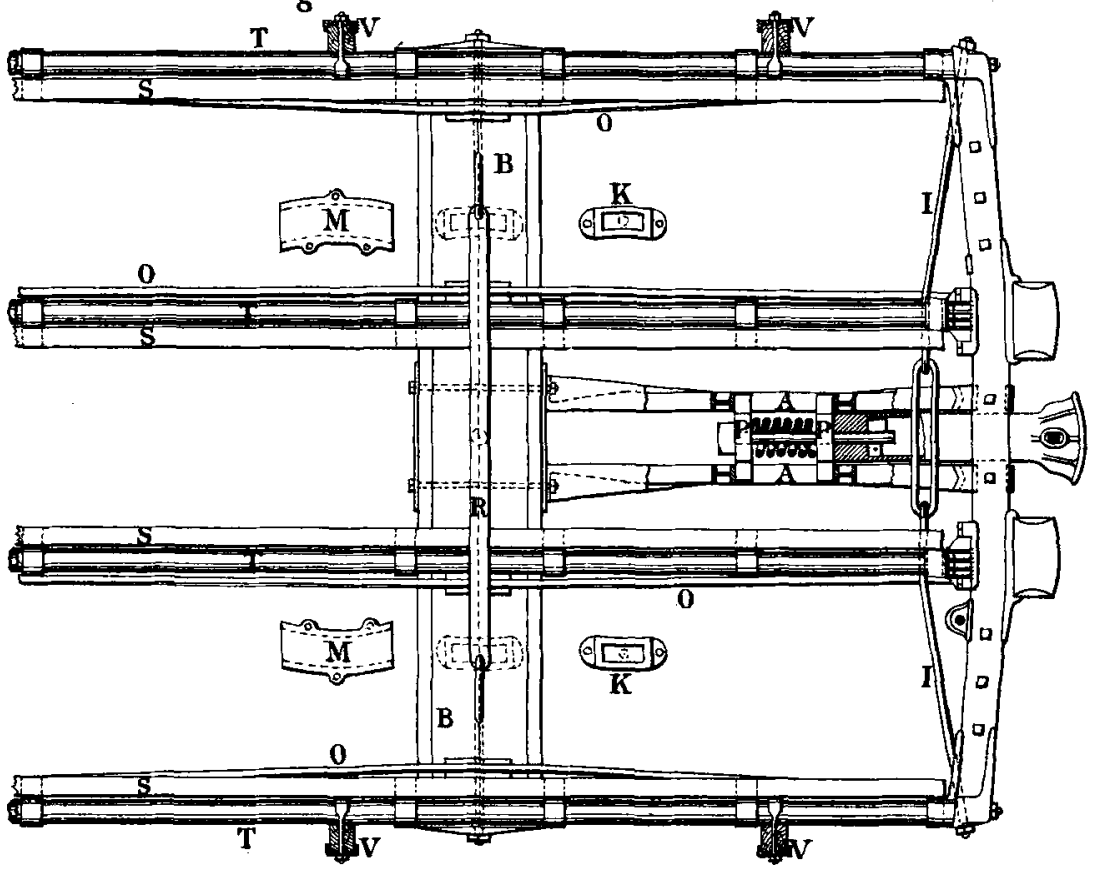

Fig: 4. Longitudinal Section of Wagon End.

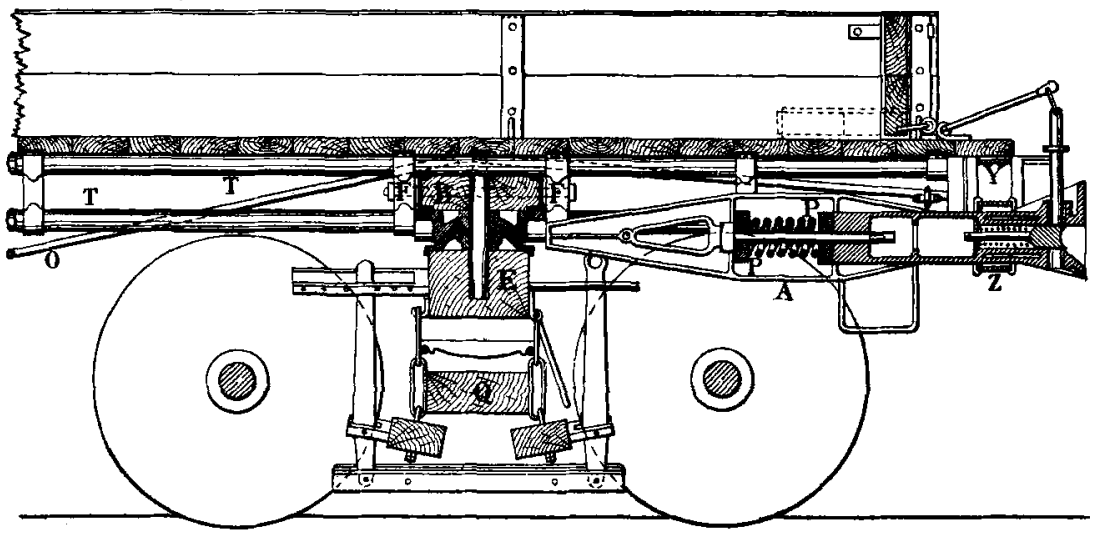

(Mechanical Engineers 1890)

Scale $1 / 30^{\text {th }}$

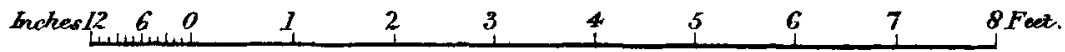


TUBE-FRAME RAILWAY WAGONS. Plate 139.

Fig. 5. Transverse Section of Wagon Body at XX Plate 137.

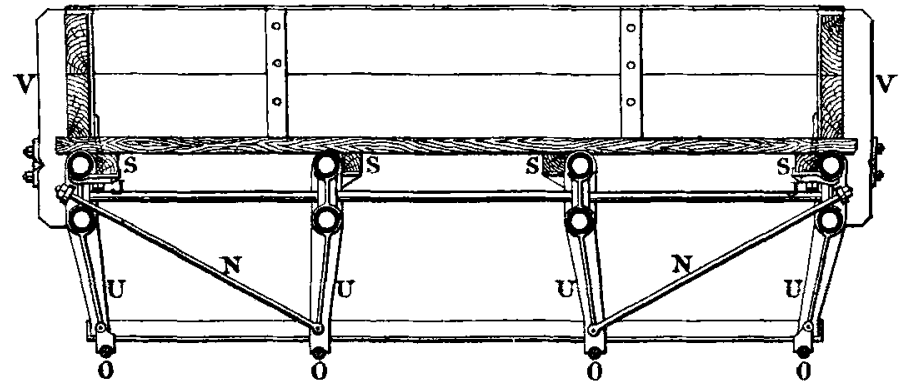

Fig. 6. End Elevation of Wagon Body.

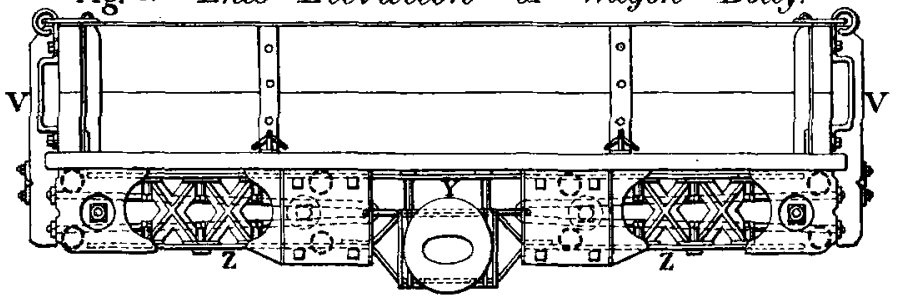

Fig. 7. End Elevation with Headstock bared.

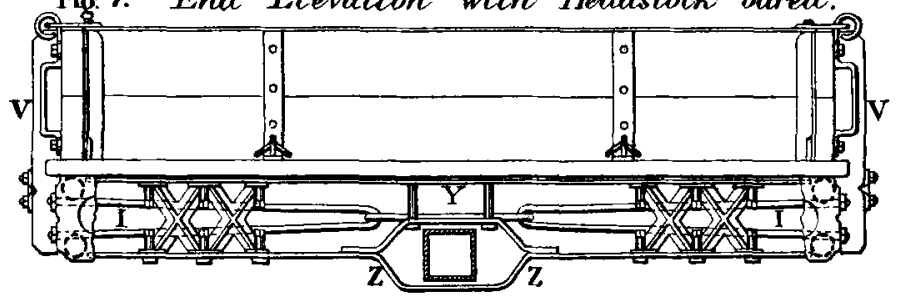

Fig. 8. Transverse Section of Wagon Body on Bogie Truck.

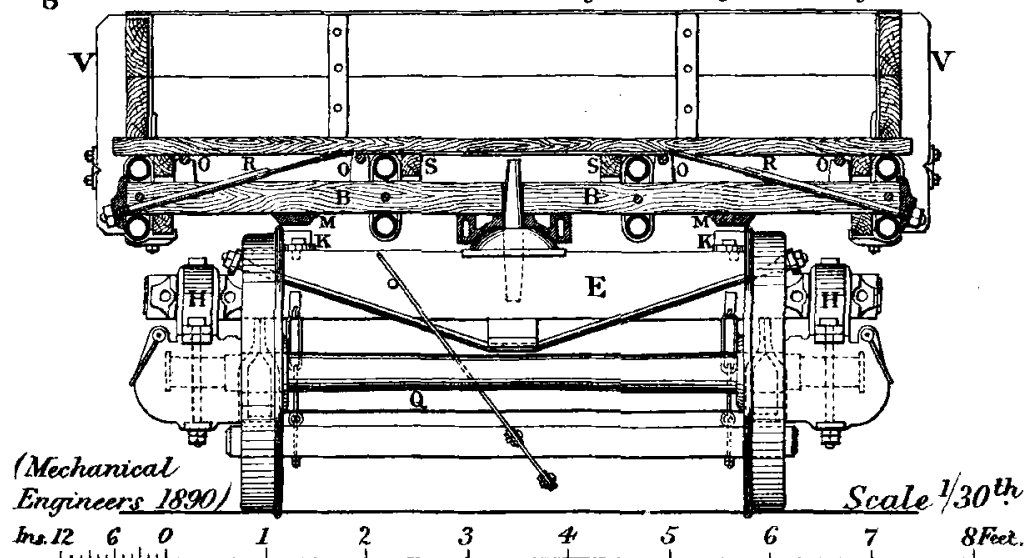

Downloaded from pme.sagepub.com at Kungl Tekniska Hogskolan / Royal Institute of Technology on March 13, 
TUBE-FRAME RAILWAY WAGONS.

Plate 140.

Fig. 9. Rounding curve of 55 feet radius.

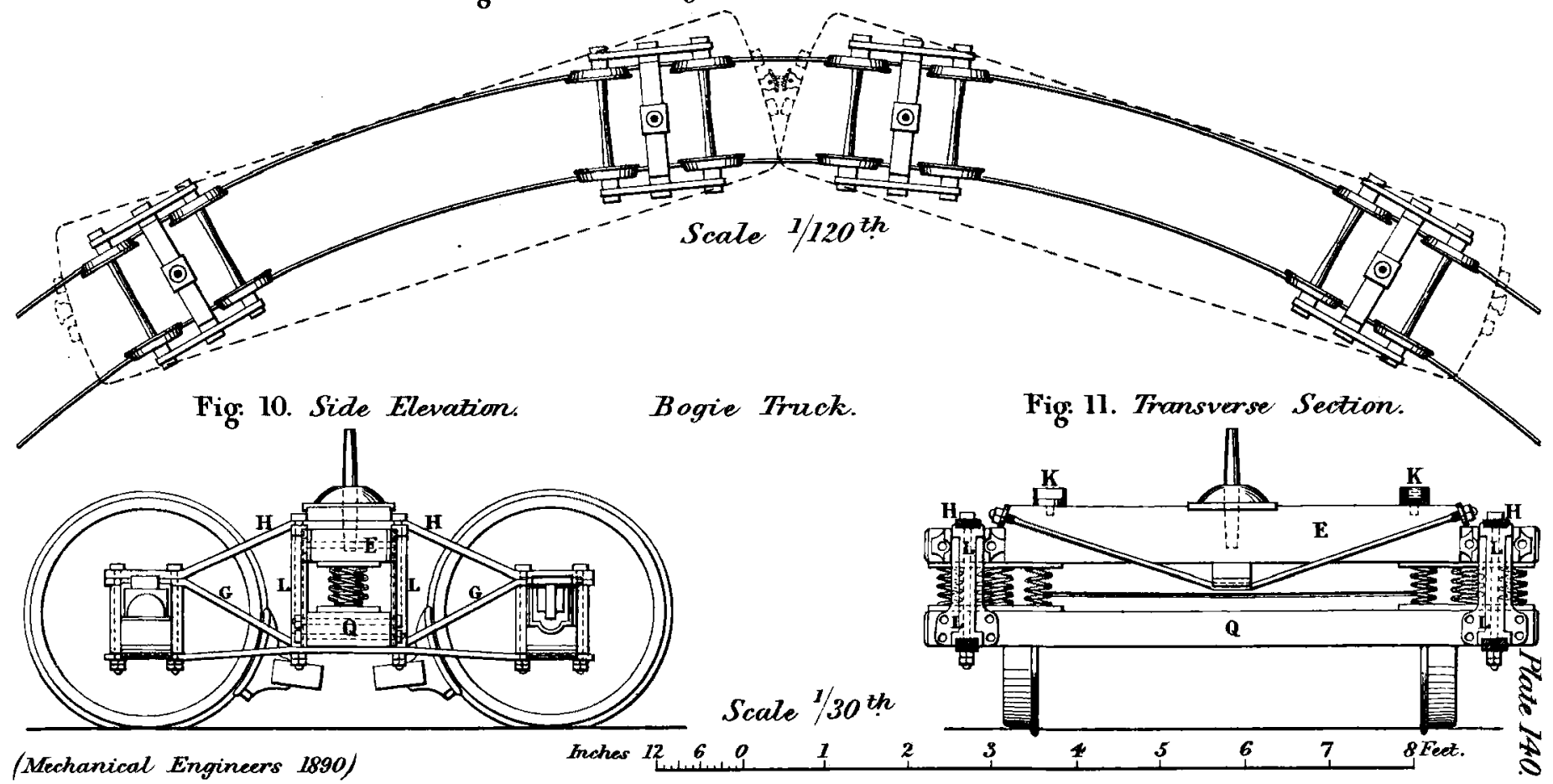


Fig: 12. Jointing of Tubes.

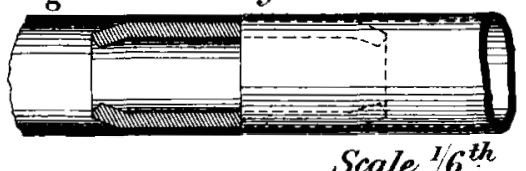

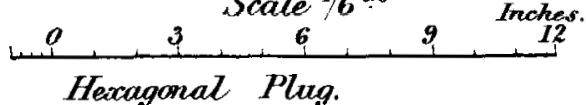
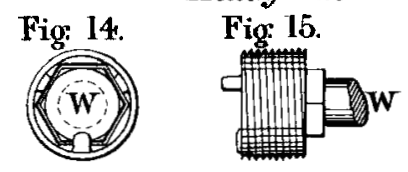

Fig: 16.

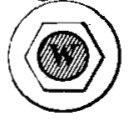

TUBE-FRAME RAILWAY WAGONS.
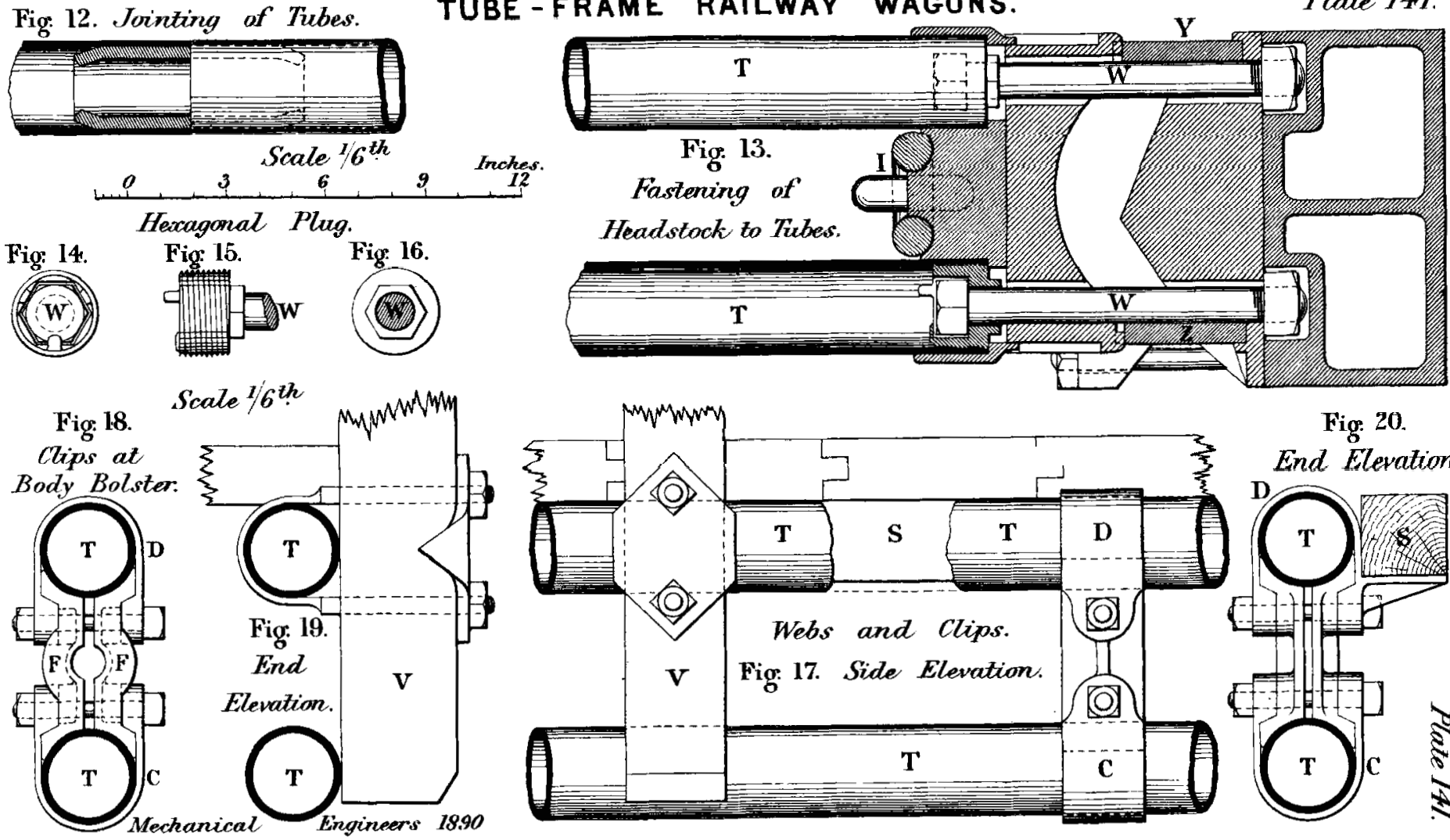

Fig: 20.

End Elevation.

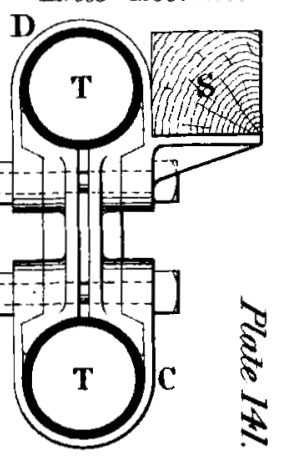


Lov-sided Gondola Wagon with Drop Ends.

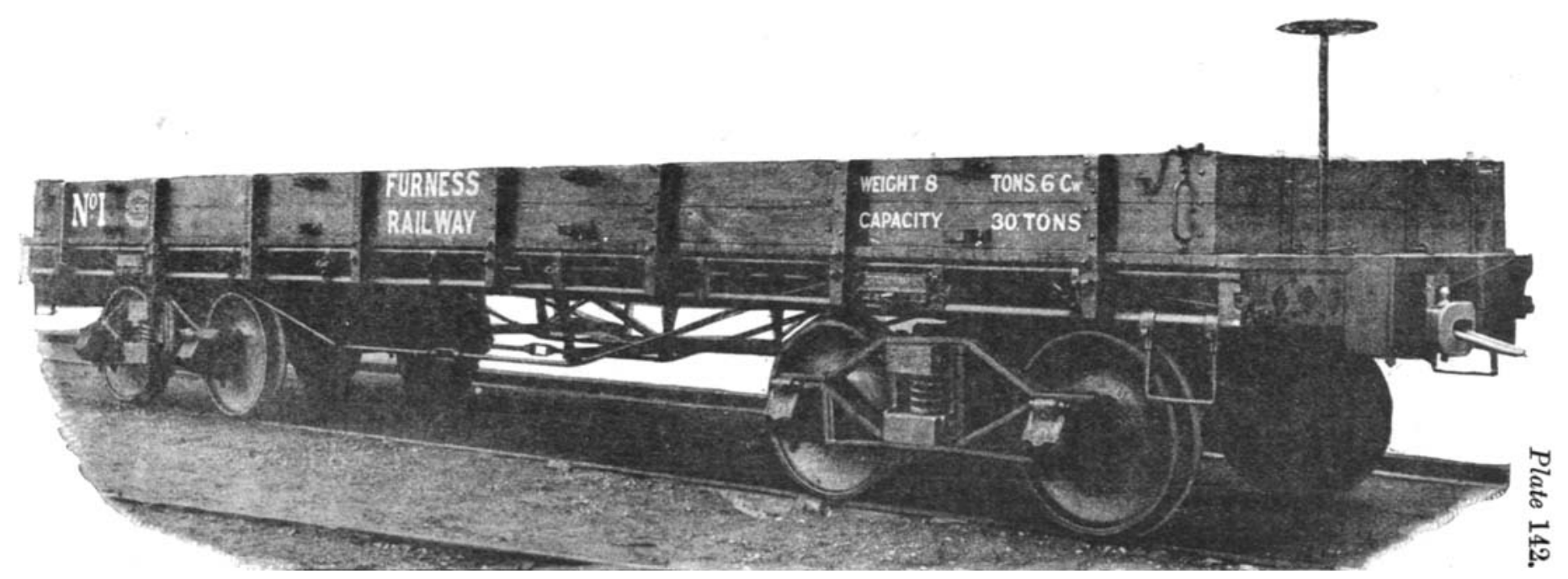


High-sided Gondola Wagon, built with or without Drop Side Doors.

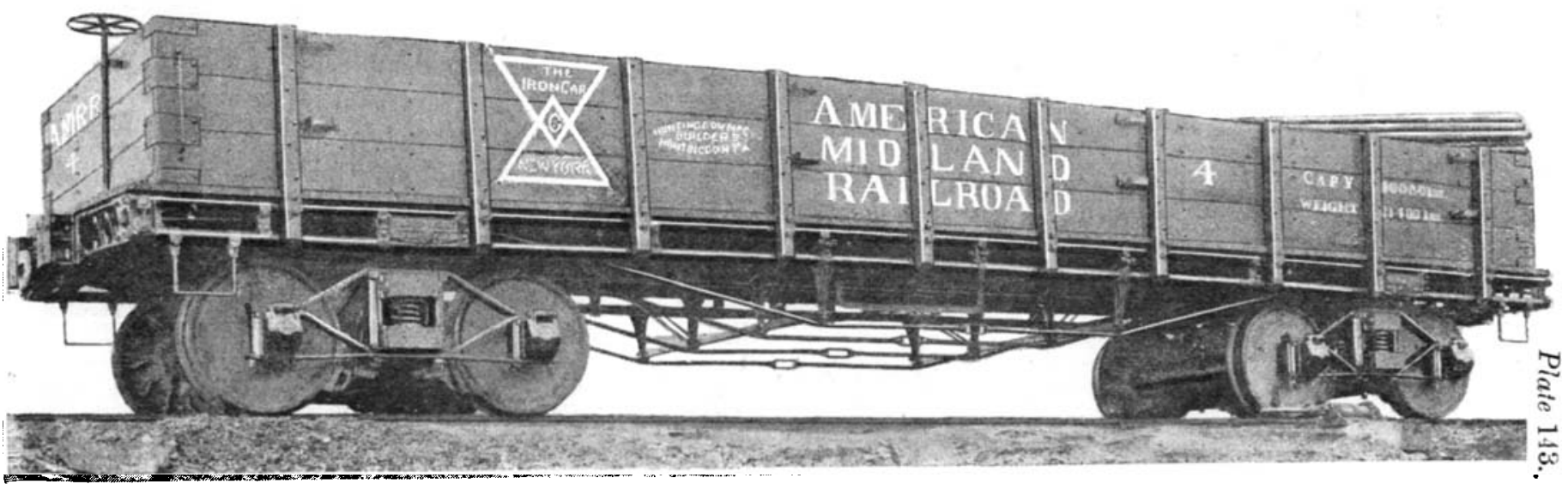


Hopper-Bottom Coal Wagon.

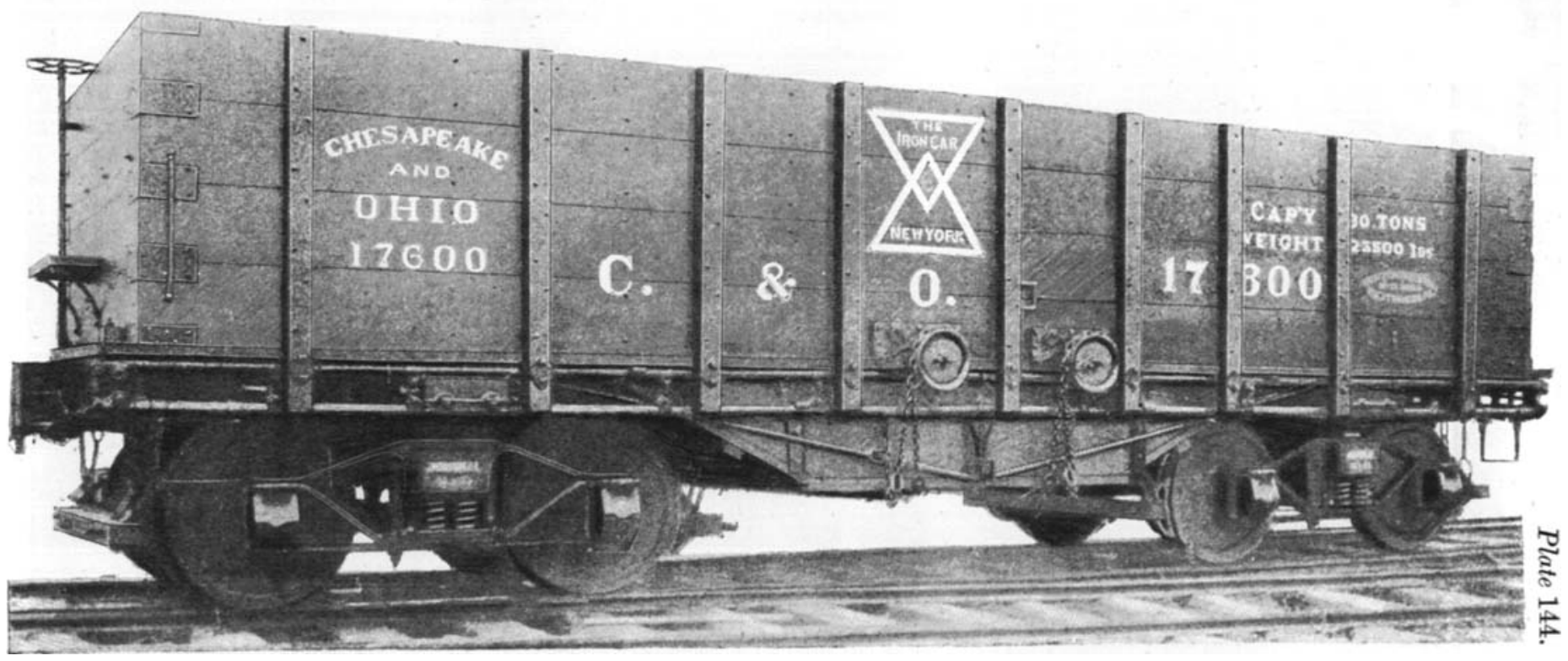




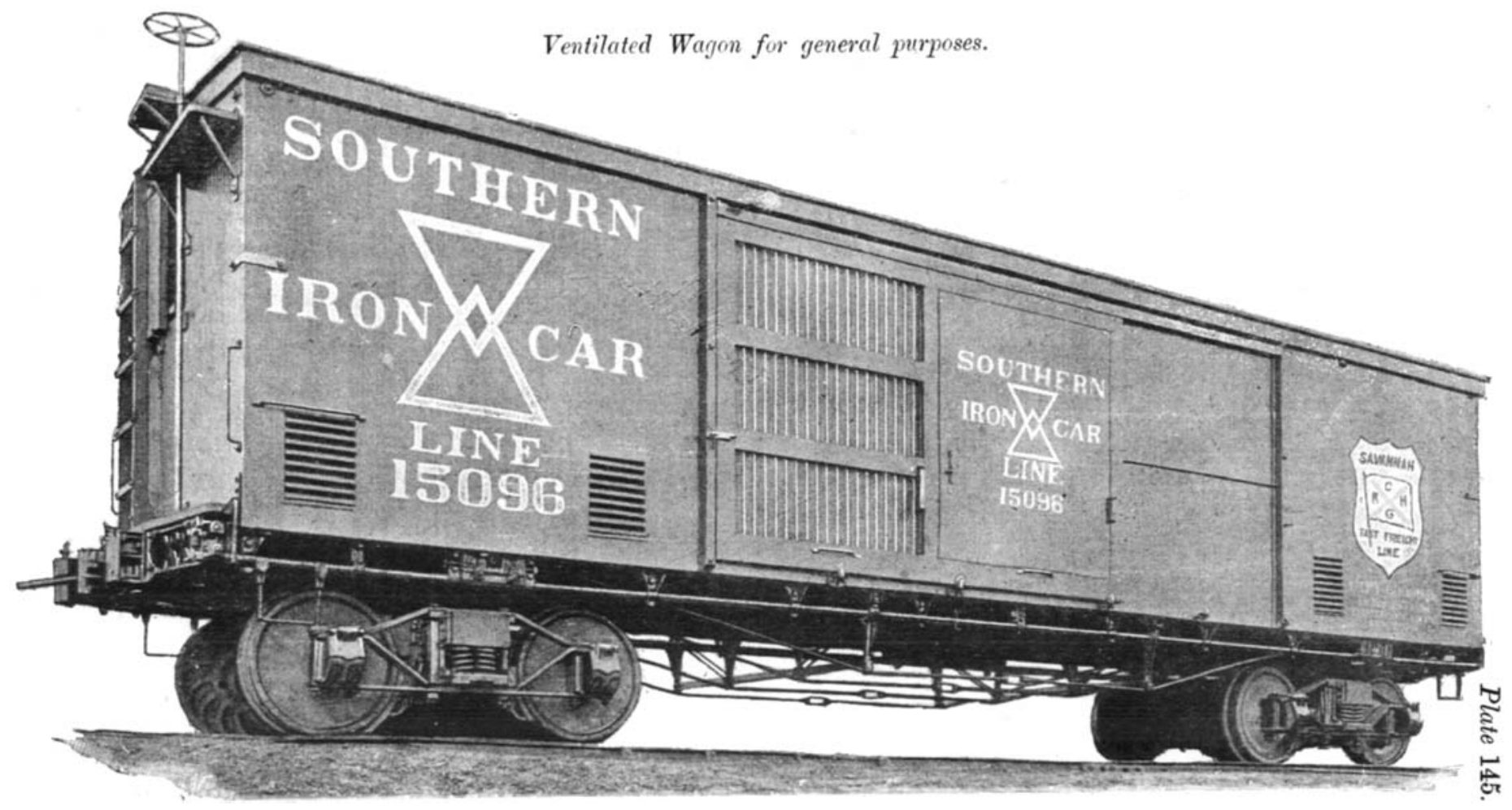




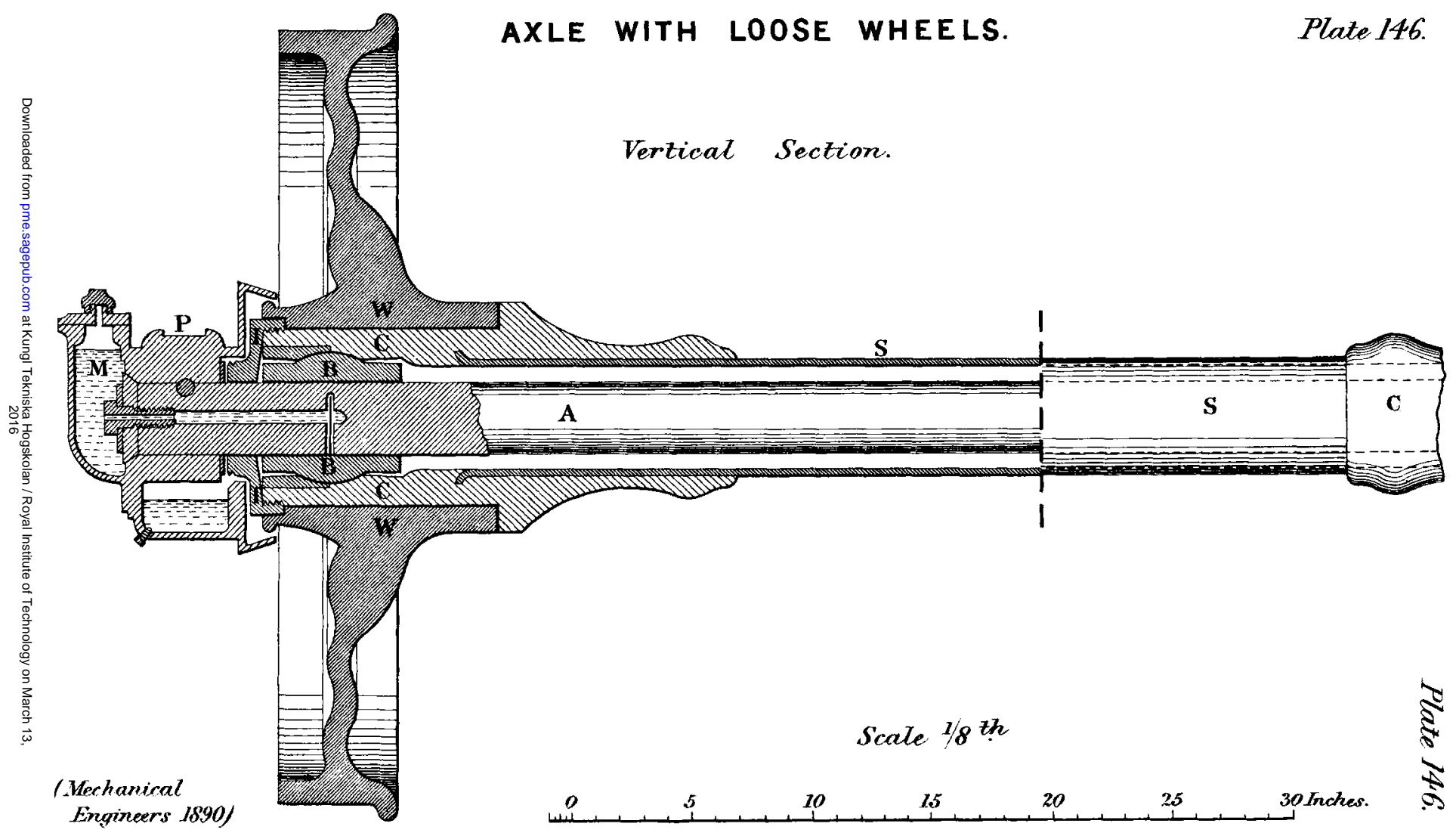

